\title{
Detachment of Chain-Forming Neuroblasts by Fyn-Mediated Control of cell- cell Adhesion in the Postnatal Brain
}

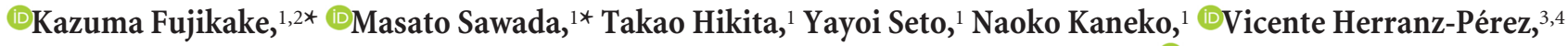 \\ Natsuki Dohi, ${ }_{1}^{1}$ Natsumi Homma, ${ }^{1}$ Satoshi Osaga, ${ }^{5}$ Yuchio Yanagawa, ${ }^{6}$ Toshihiro Akaike, ${ }^{7}$ OJose Manuel García-Verdugo, ${ }^{3}$ \\ ๑Ditsuharu Hattori, ${ }^{8}$ Kazuya Sobue, ${ }^{2}$ and $\odot$ Kazunobu Sawamoto ${ }^{1,9}$ \\ Departments of ${ }^{1}$ Developmental and Regenerative Biology, ${ }^{2}$ Anesthesiology and Intensive Care Medicine, Nagoya City University Graduate School of \\ Medical Sciences, Nagoya 467-8601, Japan, ${ }^{3}$ Laboratorio de Neurobiología Comparada, Instituto Cavanilles, Universidad de Valencia, CIBERNED, 46980 \\ Valencia, Spain, ${ }^{4}$ Predepartamental Unit of Medicine, Faculty of Health Sciences, Universitat Jaume I, 12071 Castelló de la Plana, Spain, ${ }^{5}$ Clinical Research \\ Management Center, Nagoya City University Hospital, Nagoya 467-8601, Japan, ${ }^{6}$ Department of Genetic and Behavioral Neuroscience, Gunma University \\ Graduate School of Medicine, Maebashi 371-8511, Japan, ${ }^{7}$ Biomaterials Center for Regenerative Medical Engineering, Foundation for Advancement of \\ International Science, Tsukuba 305-0821, Japan, ${ }^{8}$ Department of Biomedical Science, Graduate School of Pharmaceutical Sciences, Nagoya City University, \\ Nagoya 467-8603, Japan, and ${ }^{9}$ Division of Neural Development and Regeneration, National Institute for Physiological Sciences, Okazaki 444-8585, Japan
}

In the rodent olfactory system, neuroblasts produced in the ventricular-subventricular zone of the postnatal brain migrate tangentially in chain-like cell aggregates toward the olfactory bulb (OB) through the rostral migratory stream (RMS). After reaching the OB, the chains are dissociated and the neuroblasts migrate individually and radially toward their final destination. The cellular and molecular mechanisms controlling cell-cell adhesion during this detachment remain unclear. Here we report that Fyn, a nonreceptor tyrosine kinase, regulates the detachment of neuroblasts from chains in the male and female mouse OB. By performing chemical screening and in vivo loss-of-function and gain-of-function experiments, we found that Fyn promotes somal disengagement from the chains and is involved in neuronal migration from the RMS into the granule cell layer of the OB. Fyn knockdown or Dab1 (disabled-1) deficiency caused p120catenin to accumulate and adherens junction-like structures to be sustained at the contact sites between neuroblasts. Moreover, a Fyn and $\mathrm{N}$-cadherin double-knockdown experiment indicated that Fyn regulates the $\mathrm{N}$-cadherin-mediated cell adhesion between neuroblasts. These results suggest that the Fyn-mediated control of cell-cell adhesion is critical for the detachment of chain-forming neuroblasts in the postnatal $\mathrm{OB}$.

Key words: adhesion; neuronal migration; olfactory bulb; rostral migratory stream

Significance Statement

In the postnatal brain, newly born neurons (neuroblasts) migrate in chain-like cell aggregates toward their destination, where they are dissociated into individual cells and mature. The cellular and molecular mechanisms controlling the detachment of neuroblasts from chains are not understood. Here we show that Fyn, a nonreceptor tyrosine kinase, promotes the somal detachment of neuroblasts from chains, and that this regulation is critical for the efficient migration of neuroblasts to their destination. We further show that Fyn and Dab1 (disabled-1) decrease the cell-cell adhesion between chain-forming neuroblasts, which involves adherens junction-like structures. Our results suggest that Fyn-mediated regulation of the cell-cell adhesion of neuroblasts is critical for their detachment from chains in the postnatal brain.

\section{Introduction}

The dynamic control of cell-cell adhesion is an important process in brain development and function. Migrating neurons continuously change their cell-cell adhesion state by destroying and reconstructing adhesion structures in various aspects of brain development, such as exit from the neurogenic niche 
(Famulski et al., 2010; Itoh et al., 2013) and the maintenance and termination of neuronal migration (Kawauchi et al., 2010; Sekine et al., 2012; Luccardini et al., 2013). Thus, elucidating the mechanisms controlling the cell adhesion of neural cells could provide new insight for understanding brain morphogenesis and novel strategies for brain pathologies.

The chain migration of neuroblasts in the postnatal rodent brain involved in olfaction is a powerful model for examining the dynamics of cell adhesion during neuronal migration (Ghashghaei et al., 2007; Sawada et al., 2011a; Kaneko et al., 2017). In the postnatal brain, neuroblasts are continuously generated from neural stem cells in the ventricular-subventricular zone (V-SVZ; Doetsch et al., 1999). Neuroblasts generated in the V-SVZ form chain-like cell aggregates (Lois et al., 1996; Wichterle et al., 1997; Sawamoto et al., 2006) and migrate toward the olfactory bulb (OB) through the rostral migratory stream (RMS; Luskin, 1993; Lois and Alvarez-Buylla, 1994). During chain migration in the RMS, neuroblasts attach to their neighboring neuroblasts and migrate at a high speed along each other by dynamically changing their cell-cell adhesion (Tomasiewicz et al., 1993; Cremer et al., 1994; Ono et al., 1994; Emsley and Hagg, 2003; Belvindrah et al., 2007) and cell morphology (Hikita et al., 2014). After arriving at the $\mathrm{OB}$, neuroblasts detach from the neuronal chains and start to migrate individually, eventually becoming integrated into the appropriate neuronal circuits (Luskin, 1993; Lois and AlvarezBuylla, 1994; García-González et al., 2017; Petri et al., 2017; Sawada et al., 2018) to contribute to various olfactory functions (Gheusi et al., 2000; Breton-Provencher et al., 2009; Moreno et al., 2009; Sakamoto et al., 2014). In this process, the transition from the chain to individual neuron migration is believed to be critical for maintaining the OB structure and function. Previous studies suggest that extracellular matrix molecules such as Reelin (Reln), Tenascin-R, and Prokineticin 2 (PK2) have important roles in the detachment of neuroblasts from chains (Hack et al., 2002; Saghatelyan et al., 2004; Ng et al., 2005). In addition, the downregulation of the sphingosine 1-phosphate receptor-1 (S1P1) promotes neuroblast detachment in the postnatal OB (Alfonso et al., 2015). However, the mechanism regulating cell-cell adhesion during the detachment process of chain migration remains unknown.

In this report, we describe the cellular and molecular mechanisms controlling the detachment of neuroblasts from chains in the postnatal OB. A chemical screen of 287 target-known inhibitors revealed that PP2, an Src family tyrosine kinase inhibitor, prevented the detachment of neuroblasts from chains. We further found that Fyn, an Src family tyrosine kinase member, controls cell-cell adhesion and promotes neuroblast detachment from the postnatal RMS.

\section{Materials and Methods}

Animals. Wild-type (WT) male and female Institute of Cancer Research (ICR) mice were purchased from Japan SLC (RRID:IMSR_TAC:icr; https://www.

Foundation for Life Sciences and Arts (to K.S.), Grant-in-Aid for Research at Nagoya City University (to K.S.), and the Takeda Science Foundation (to K.S.). We thank the Screening Committee of Anticancer Drugs supported by a Grantin-Aid for Scientific Research on Innovative Areas, Scientific Support Programs for Cancer Research (MEXT, Japan) for providing the SCADS Inhibitor Kits; K. Nakajima for the anti-ApoER2 antibody; H. Jinnou for the N-Cadhering-KD plasmids; I. Nomura, H. Takase, T. Miyamoto, and I. Miyoshi for technical support; and Sawamoto laboratory members for discussions.

${ }^{*}$ K.F. and M.S. contributed equally to this work.

The authors declare no competing financial interests.

Correspondence should be addressed to Dr. Kazunobu Sawamoto, Department of Developmental and Regenerative Biology, Nagoya City University Graduate School of Medical Sciences, 1 Kawasumi, Mizuho-cho, Mizuho-ku, Nagoya, Aichi 467-8601, Japan. E-mail: sawamoto@med.nagoya-cu.ac.jp.

DOI:10.1523/JNEUROSCI.1960-17.2018

Copyright $\odot 2018$ the authors $\quad 0270-6474 / 18 / 384599-12 \$ 15.00 / 0$ taconic.com/mouse-model/icr). Dab1 $1^{\text {yot/yot }}$ (yotari) mice were described previously (Yoneshima et al., 1997; RRID:IMSR_RBRC05456; http://www2. brc.riken.jp/lab/animal/detail.php?brc_no=RBRC05456). GAD67-EGFP mice were described previously (Tamamaki et al., 2003; RRID:IMSR_RBRC03674; http://www2.brc.riken.jp/lab/animal/detail.php?brc_no=RBRC03674). All of the animal experimental procedures complied with national regulations and guidelines, were reviewed by the Institutional Laboratory Animal Care and Use Committee, and were approved by the President of Nagoya City University.

Chemical screening. V-SVZ tissues were dissected from postnatal day 0 (P0) to P1 WT male and female ICR pups, cut into blocks (150-200 $\mu \mathrm{m}$ in diameter), and embedded in $60 \%$ Matrigel (BD Biosciences)/L- 15 medium. SCADS Inhibitor Kits were provided by the Screening Committee of Anticancer Drugs supported by Grant-in-Aid for Scientific Research on Innovative Areas, Scientific Support Programs for Cancer Research (Ministry of Education, Culture, Sports, Science and Technology of Japan) or purchased from EMD Millipore. For the initial screen, 287 chemical inhibitors at $1 \mu \mathrm{M}$ were added to the cells, which were fixed $36 \mathrm{~h}$ later. The ratio of chain-forming cells to all of the cells migrating out from the pellet was calculated and compared with the control (no inhibitor) group. Inhibitors causing a statistically significant increase in chain formation were further assessed in a second screening. For the second screening, the chemical inhibitors were added to cells at various concentrations $(0.2-50 \mu \mathrm{M})$, and the migratory behaviors of the cells were recorded using an inverted light microscope (Colibri, Carl Zeiss) every 5 min for $10 \mathrm{~h}$. The effective inhibitor PP2 (Hanke et al., 1996) and its inactive analog PP3 were purchased from EMD Millipore.

Plasmids. Knockdown (KD) vectors were generated as described previously (Ota et al., 2014; Jinnou et al., 2018). Briefly, the targeted sequences of the mouse Fyn and Src genes were inserted into a modified Block-iT Pol II miR RNAi entry vector containing emerald green fluorescent protein (EmGFP) or DsRed-Express (Invitrogen). These DNA sequences were then inserted into pCAGGS destination vectors. $\mathrm{N}$ cadherin-KD vectors were reported previously (Jinnou et al., 2018). For the Fyn-overexpression plasmid, mouse Fyn cDNA was amplified by PCR and inserted into the SalI site of the PEGFP-C1 vector (Clontech Laboratories). To prepare the Reelin-containing conditioned medium (CM), HEK293T cells were transfected with pcDNA3-Reelin (D'Arcangelo et al., 1997), and their supernatant was concentrated using an Amicon Ultra-15 Centrifugal Filter (EMD Millipore).

In vivo electroporation. Electroporation in the postnatal brain was performed as described previously (Ota et al., 2014). Briefly, P1 WT male and female pups were anesthetized by hypothermia or spontaneous inhalation of isoflurane and fixed to a stereotaxic injection apparatus ( David Kopf Instruments). Fast green solution $(0.01 \%)$ containing $8 \mu \mathrm{m}$ of plasmid was injected into the lateral ventricles of the right hemispheres (stereotaxic coordinates: $+2.0 \mathrm{~mm}$ anterior, $1.25 \mathrm{~mm}$ lateral to lambda, and $1.6 \mathrm{~mm}$ deep). Plasmids were introduced into the V-SVZ cells by an electroporator (catalog \#CUY-21SC, Nepagene) with an electrode (catalog \#CUY650P5, Nepagene). For slice culture experiments (see Fig. 2), control, and Fyn-KD plasmids were transferred by in vivo electroporation with an interval of $12 \mathrm{~h}$ before the brain slices were prepared. In the double-KD study (see Fig. $5 e-g$ ), $4 \mu \mathrm{g}$ of Fyn-KD plasmid and $4 \mu \mathrm{g}$ of $\mathrm{N}$-cadherin-KD plasmid were mixed and used for electroporation.

Transplantation. The V-SVZ tissues were dissected from P2-P4 male and female GAD67-EGFP;Dab1 $1^{\text {yot/+ }}$ or GAD67-EGFP;Dab1 $1^{\text {yot/yot }}$ pups and dissociated with trypsin-EDTA (Invitrogen). The cells were resuspended in L15 medium (Invitrogen) containing $40 \mu \mathrm{g} / \mathrm{ml}$ DNase I (Roche) and transplanted into the V-SVZ of P1 WT male and female pups (stereotaxic coordinates: $+1.8 \mathrm{~mm}$ anterior, 1.4 and $1.5 \mathrm{~mm}$ lateral to lambda, and 1.3-2.0 mm deep). In the Fyn overexpression experiments (see Fig. $4 d-f$ ), pEGFP-C1 or pEGFP-C1-Fyn plasmids were introduced into dissociated $\mathrm{Dabl}^{+/+}$and $\mathrm{Dab1} 1^{\text {yot } / \text { yot }}$ cells by electroporation using an Amaxa Nucleofector II device (Lonza). The cells were then immediately transplanted into the V-SVZ of WT male and female pups.

Western blotting. Western blotting (WB) was performed as described previously (Ota et al., 2014). The V-SVZ tissues were dissected manually (Ota et al., 2014) and homogenized in the lysis buffer (20 mm Tris- $\mathrm{HCl}$, 
pH 8.0, $100 \mathrm{~mm} \mathrm{NaCl}, 1 \mathrm{~mm}$ EDTA, $10 \mathrm{mg} / \mathrm{ml}$ leupeptin, and $10 \mathrm{~mm}$ phenylmethylsulfonyl fluoride). For WB using brain tissues dissected by laser-capture microdissection, freshly frozen WT brains were cut into $20-\mu \mathrm{m}$-thick coronal sections using a cryostat (Leica), and the regions of interest were dissected using laser-capture microdissection (PALM MicroBeam, Carl Zeiss) according to the manufacturer instructions. Proteins were separated by SDS-PAGE and transferred to a polyvinylidene difluoride membrane. The membrane was blocked in 5\% skim milk (Fig. $1 c$ ) or $1 \%$ bovine serum albumin (Fig. 1e) in Tris-buffered saline containing $0.01 \%$ Tween 20 , and incubated with primary antibodies followed by horseradish peroxidase-conjugated secondary antibodies (Dako). Signals were detected using enhanced luminal-based chemiluminescent Western blotting detection reagent (GE Healthcare) and measured with a cooled charge-coupled device camera (LAS3000mini; Fujifilm). The following primary antibodies were used: rabbit anti-Src antibody, 1:1000 (catalog \#2109S, Cell Signaling Technology; RRID: AB_10693939); rabbit anti-Fyn antibody, 1:1000 (catalog \#4023S, Cell Signaling Technology; RRID:AB_10698604); rabbit anti-phosphorylated Fyn antibody, 1:1000 (catalog \#ab182661, Abcam); rabbit anti-Lck antibody, 1:1000 (catalog \#9320S, Cell Signaling Technology; RRID: AB_10695097); and mouse anti-actin, 1:2000 (catalog \#A5228, SigmaAldrich; RRID:AB_262054).

Time-lapse imaging of migrating cells in brain slices. Brain slices were prepared for time-lapse imaging from $\mathrm{P} 6 \mathrm{WT}$ mice at $5 \mathrm{~d}$ postelectroporation (dpe), as reported previously (Ota et al., 2014), with slight modifications. The dissected brain was cut into $150-\mu \mathrm{m}$-thick sagittal sections using a vibratome (catalog \#VT1200S, Leica). The slices were placed on a stage-top imaging chamber (Warner Instruments) under continuous perfusion at $1 \mathrm{ml} / \mathrm{min}$ with artificial CSF $(125 \mathrm{~mm} \mathrm{NaCl}, 26 \mathrm{~mm}$ $\mathrm{NaHCO}_{3}, 3 \mathrm{~mm} \mathrm{KCl}, 2 \mathrm{~mm} \mathrm{CaCl}, 1.3 \mathrm{~mm} \mathrm{MgCl}_{2}, 1.25 \mathrm{~mm} \mathrm{NaH} \mathrm{PO}_{4}$, and $20 \mathrm{~mm}$ glucose, $\mathrm{pH} 7.4 ; 38^{\circ} \mathrm{C}$, bubbled with $95 \% \mathrm{O}_{2}$ and $5 \% \mathrm{CO}_{2}$ ). The migratory behaviors of fluorescently labeled cells in the cultured RMS and OB tissues were recorded using a confocal laser-scanning microscope (catalog \#LSM710, Carl Zeiss) equipped with GaAsP detectors and a $20 \times$ objective lens. Images were taken at $10 \mu \mathrm{m}$ steps, $40 \mu \mathrm{m}$ deep, and automatically were acquired every $5 \mathrm{~min}$ for $10 \mathrm{~h}$. For slice-culture imaging in the transplantation study, $200-\mu \mathrm{m}$-thick sagittal brain sections were prepared using a vibratome (catalog \#VT-1200, Leica) and cultured on a filter membrane (EMD Millipore) in Neurobasal medium (Invitrogen), supplemented with 10\% fetal bovine serum, 2\% NeuroBrew-21 (Invitrogen), $2 \mathrm{~mm}$ L-glutamine (Invitrogen), and 50 $\mathrm{U} / \mathrm{ml}$ penicillin-streptomycin (Invitrogen) in a stage-top chamber at $37^{\circ} \mathrm{C}$ and in a $5 \% \mathrm{CO}_{2}$ incubation system (Tokai Hit). Time-lapse images were captured at $8 \mathrm{~min}$ intervals for $6-12 \mathrm{~h}$ using an inverted light microscope (Colibri, Carl Zeiss) with a $20 \times$ objective lens. To quantify the speed of migrating cells in the captured images, cells within the anterior RMS (aRMS) with a monopolar or bipolar shape were traced using the manual tracking plugin in the ImageJ software $(\mathrm{NIH}$, Bethesda, MD; RRID:SCR_003070). All of the migrating cells that could be continuously tracked for at least $5 \mathrm{~h}$ were used for this analysis.

In vitro culture of migrating cells. The dissociated V-SVZ cells from P0-P1 WT mice were transfected with either pCAGGS-EmGFP-LacZmiRNA or pCAGGS-EmGFP-Fyn-miRNA using an Amaxa Nucleofector II device (Lonza). The transfected cells were cultured in a hanging drop in Neurobasal medium (Invitrogen) containing 2\% B-27 supplement (Invitrogen), $2 \mathrm{~mm}$ L-glutamine (Invitrogen), and $50 \mathrm{U} / \mathrm{ml}$ penicillin-streptomycin (Invitrogen) for $1 \mathrm{~d}$ and then seeded onto an N-cadherin-Fc-coated glass-bottom dish (Yue et al., 2010; Haque et al., 2012, 2015). The live imaging of migrating cells was performed under an inverted light microscope (Colibri, Carl Zeiss) using a $20 \times$ objective lens. Time-lapse images were automatically acquired at $6 \mathrm{~min}$ intervals for 6-12 h. In the neuronal culture in Matrigel (see Fig. 4a), the V-SVZ cells were transfected with either pCAGGS-EmGFP-LacZ-miRNA or -FynmiRNA by in vivo electroporation. At 1 dpe, the transfected V-SVZ cells were dissociated and cultured for $1 \mathrm{~d}$ and treated with Reelin-containing CM. For analysis, all of the GFP-labeled cells were counted, and the proportion of individual (nonattached) $\mathrm{GFP}^{+}$cells in the total GFPlabeled population was calculated (see Fig. $4 a$ ).
Transmission electron microscopy. Samples were prepared for transmission electron microscopy as described previously (Ogino et al., 2016). Briefly, P8 WT and yotari brains were fixed with $2 \%$ paraformaldehyde (PFA) and $2.5 \%$ glutaraldehyde in $0.1 \mathrm{M}$ cacodylate buffer, $\mathrm{pH} 7.4$, at $4^{\circ} \mathrm{C}$, treated with $2 \% \mathrm{OsO}_{4}$ in the same buffer at $4{ }^{\circ} \mathrm{C}$, dehydrated with a graded series of ethanol, and embedded in Quetol 812 epoxy resin for $48 \mathrm{~h}$ at $60^{\circ} \mathrm{C}$. Ultrathin sections were prepared from the embedded tissue blocks using an ultramicrotome (Reichert-Jung) and stained with $2 \%$ uranyl acetate in distilled water for $15 \mathrm{~min}$ and with modified Sato's lead solution (Hanaichi et al., 1986) for $5 \mathrm{~min}$. Electron microscopy images of the cellular contact regions between chain-forming neuroblasts were acquired using a transmission electron microscope (catalog \#JEM1011J, JEOL) fitted with a digital camera. Neuroblasts were identified by their electron-dense nucleus and cytoplasm, and multiple nucleoli, as described previously (Doetsch et al., 1997).

Immunohistochemistry and immunocytochemistry. Immunohistochemistry and immunocytochemistry were performed as previously described (Sawada et al., 2011b; Ota et al., 2014). Brains were fixed by transcardiac perfusion with $4 \%$ PFA in $0.1 \mathrm{~m}$ phosphate buffer $(\mathrm{PB}), \mathrm{pH}$ 7.4 , postfixed overnight in the same fixative, and cut into $60-\mu \mathrm{m}$-thick coronal or sagittal sections using a vibratome. For immunocytochemistry, cultured cells were fixed with 4\% PFA in $0.1 \mathrm{M} \mathrm{PB}, \mathrm{pH} 7.4$, for $10 \mathrm{~min}$ at room temperature (RT). The sections or cultured cells were incubated for $30 \mathrm{~min}$ in blocking solution (10\% normal donkey serum and $0.1 \%$ Triton X-100 in PBS), overnight at $4^{\circ} \mathrm{C}$ with the primary antibodies, and for $2 \mathrm{~h}$ at RT with Alexa Fluor-conjugated secondary antibodies (1:1000; Invitrogen) in the same solution. For immunocytochemistry using the anti-p120-catenin antibody, cells in Matrigel were treated with $100 \%$ methanol at $4^{\circ} \mathrm{C}$ for $6 \mathrm{~min}$ (see Fig. $4 b, c$ ). For the double staining of Fyn and phosphorylated Fyn, the AffiniPure Fab Fragment Donkey AntiRabbit IgG (H+L; catalog \#711-007-003, Jackson ImmunoResearch; RRID:AB_2340587) was used at 1:100 (at RT, for $1 \mathrm{~h}$ ). The following primary antibodies were used: rat anti-ApoER2 antibody, 1:100 [a gift from Dr. Kazunori Nakajima, Keio University, Tokyo, Japan (Hirota et al., 2015; RRID:AB_2336895]; rabbit anti-doublecortin (Dcx) antibody, 1:300 (catalog \#4604S, Cell Signaling Technology; RRID:AB_10693771); mouse anti-p120-catenin antibody, 1:100 (catalog \#610134, BD Transduction Laboratories; RRID:AB_397537); rabbit anti-Fyn antibody, 1:100 (catalog \#4023S, Cell Signaling Technology; RRID:AB_10698604); rabbit anti-phosphorylated Fyn antibody, 1:100 (catalog \#ab182661, Abcam); rabbit anti-GFAP antibody, 1:500 (catalog \#Z0334, Dako; RRID: AB_10013382); rat anti-GFP antibody, 1:300 (catalog \#04404-84, Nacalai Tesque; RRID:AB_10013361); and mouse anti-NeuN antibody, 1:100 (catalog \#MAB377, EMD Millipore; RRID:AB_2298772). Nuclei were stained with Hoechst 33342 (Sigma-Aldrich).

Images of fluorescently labeled cells in the RMS, OB, striatum, corpus callosum (CC), and other cerebral regions neighboring the posterior RMS (pRMS; Fig. $1 d$ ) were acquired by scanning at $2 \mu \mathrm{m}$ intervals using a confocal laser-scanning microscope (model LSM700, Carl Zeiss) with a $20 \times$ objective lens. To investigate the expression pattern of Fyn and p-Fyn, the colocalization of immunofluorescent signals was examined by scanning at $2 \mu \mathrm{m}$ intervals. All of the labeled cells in sequential sagittal sections containing both the RMS and OB were counted. For double-KD experiments (see Fig. $5 e-g$ ), all of the EmGFP ${ }^{+}$tdTomato $^{+}$cells in the sequential sagittal sections containing both the RMS and OB were counted. For the analyses of p-Fyn intensity (Fig. $1 g$ ), the p-Fyn ${ }^{+}$fluorescence signals in the $\mathrm{Dcx}^{+}$cells were acquired using the LSM700 microscope with a $20 \times$ objective lens, and quantified using ZEN software (Carl Zeiss). For the analyses of p120-catenin intensity (see Figs. 4b,c, $5 a-c)$, the p120-catenin ${ }^{+}$fluorescence signals were acquired by scanning at $1 \mu \mathrm{m}$ intervals using the LSM700 with a $40 \times$ water-immersion objective lens, and quantified using ZEN software (Carl Zeiss).

Experimental design and statistical analysis. Statistical analyses were performed using Excel (Microsoft) and EZR (Kanda, 2013). The experiments were not randomized. Sample sizes were not predetermined, but were chosen based on previous reports. For the initial chemical screen, comparisons among multiple groups were analyzed by one-way ANOVA followed by Dunnett's test. 


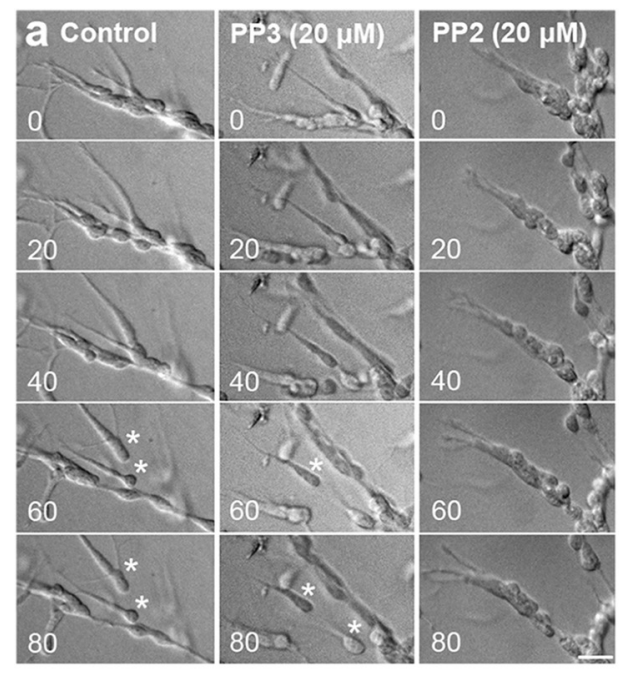

Dcx EmGFP
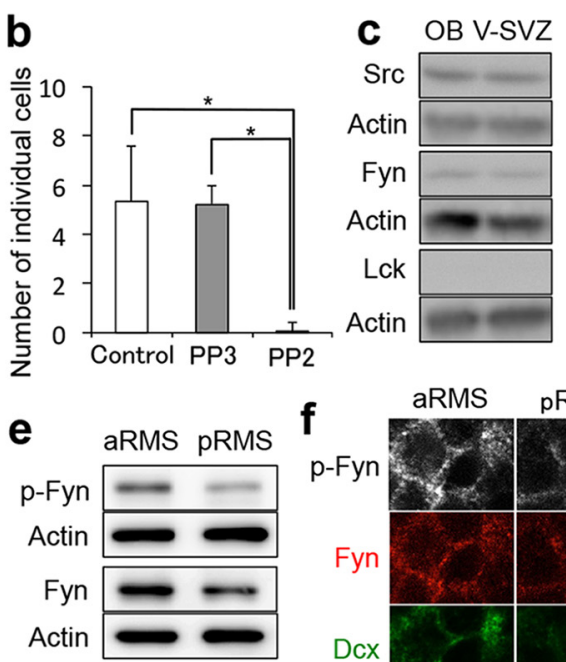

\section{d}
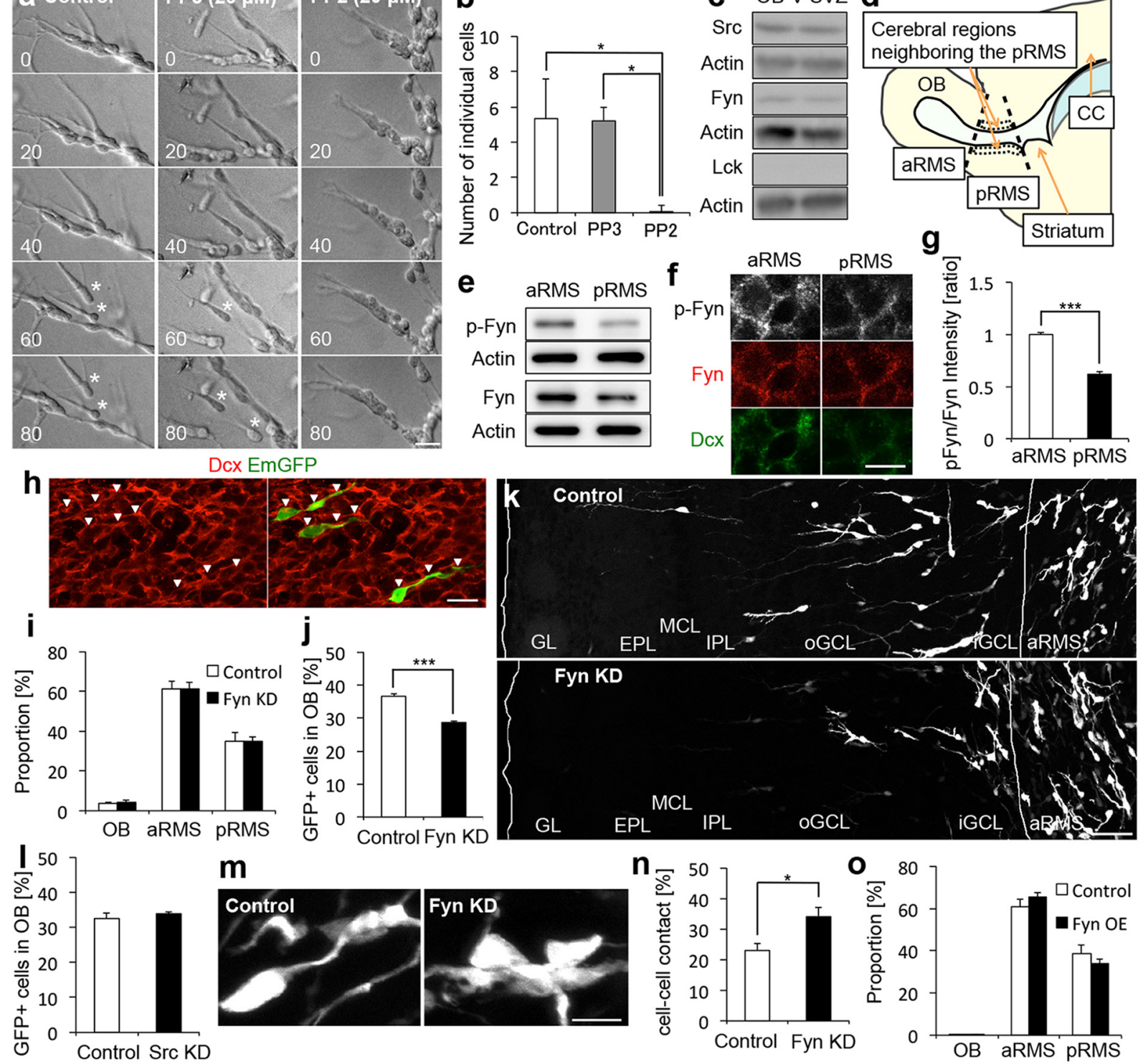

m
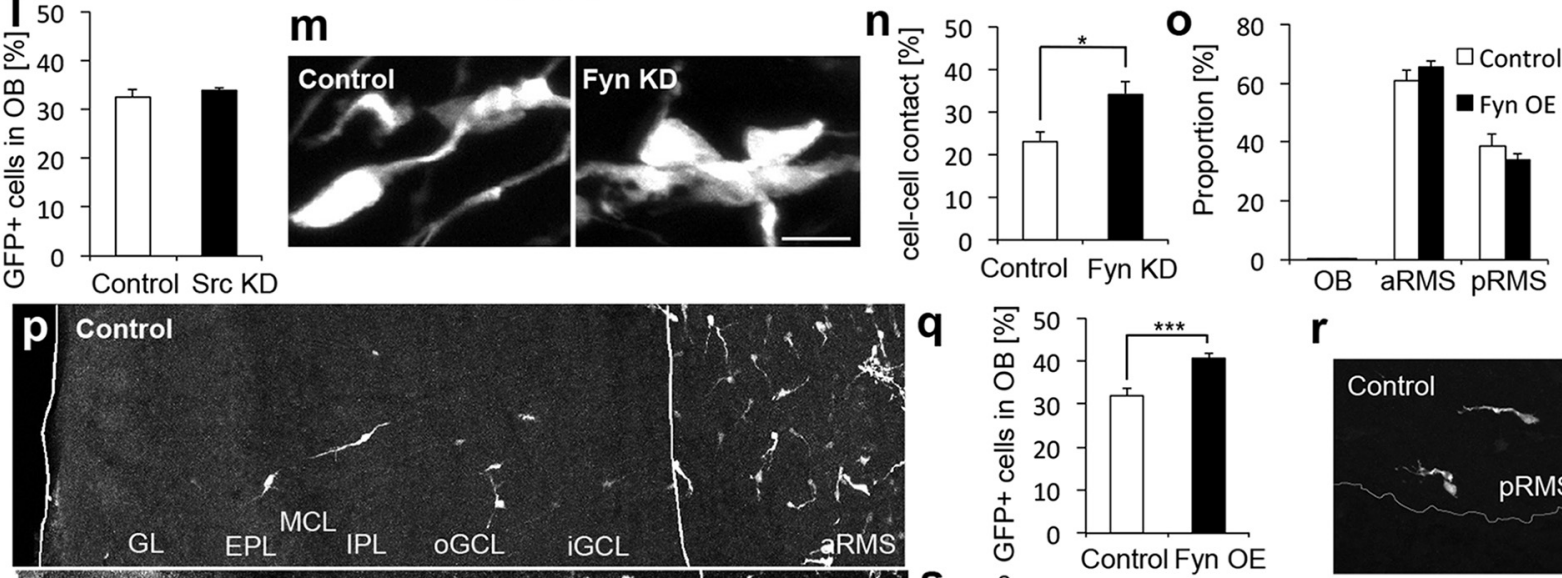

$\mathbf{r}$

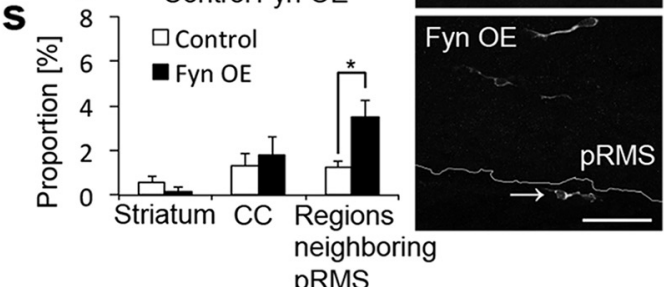

Figure 1. Fyn is involved in the cell-cell detachment of neuroblasts in the RMS. $\boldsymbol{a}, \boldsymbol{b}$, Effect of PP2 and PP3 on the chain migration of V-SVZ-derived neuroblasts. Time-lapse images of cultured migrating neurons detaching from chains in control, PP3 $(20 \mu \mathrm{m})$, and PP2 $(20 \mu \mathrm{m})$ treatment groups $(\boldsymbol{a})$. Asterisks indicate cells detached from chains $(\boldsymbol{a}$, control and PP3, 60 and 80 min, respectively). PP2, but not PP3, treatment inhibited the detachment of neuroblasts from chains $\left[\boldsymbol{b} ; F_{(2,7)}=6.53 ; p=0.025\right.$, one-way AN0VA; control vs $P P 2, t_{(7)}=5.29, p=0.041 ; P P 3$ vs $P P 2$, $t_{(7)}=5.16, p=0.045$; Tukey-Kramer test; three (control, PP3) and four (PP2) independent cultures prepared on different days]. (c) Detection of endogenous Src, Fyn, and Lck proteins in mouse V-SVZ and OB tissues by WB. Lysates of V-SVZ and OB tissues from P1 mice $(n=2)$ were subjected to WB analysis with anti-Src, anti-Fyn, and anti-Lck antibodies. Actin was used as a loading control. $\boldsymbol{d}$, Schematic illustration of the regions analyzed in $\boldsymbol{e}-\boldsymbol{g}$ and $\boldsymbol{i}-\boldsymbol{s}$. $\boldsymbol{e}$, Detection of p-Fyn in the aRMS and pRMS. $\boldsymbol{f}, \boldsymbol{g}$, Detection of p-Fyn and Fyn in the aRMS and pRMS by immunohistochemistry. Coronal OB sections prepared from P7 WT mice were stained for Dcx (green), p-Fyn (white), and Fyn (red). The relative p-Fyn intensity in Dcx ${ }^{+}$cells was significantly higher in the aRMS than in the pRMS $\left(\boldsymbol{g} ; t_{(58)}=-10.48, p=5.3 \times 10^{-15}\right.$, unpaired $t$ test; $n=30$ cells from three sections from three mice each). $\boldsymbol{h}$, Sagittal RMS sections prepared from (Figure legend continues.) 
All the numerical data were expressed as the mean \pm SEM. The normality of the data was analyzed by Kolmogorov-Smirnov test and/or Shapiro-Wilk test. For normally distributed data, a comparison of means between two independent groups was performed by unpaired $t$ test or Welch's $t$ test, where the equality of variances was examined by $F$ test. When three or more independent groups were compared, one-way ANOVA followed by Tukey-Kramer test was applied. Analyzing data from multiple observations of individual samples (mice and cells), we performed two-way repeated-measures ANOVA and post hoc $t$ test between groups with Bonferroni correction. For not normally distributed data, a comparison of medians between groups was performed by Kruskal-Wallis test followed by Steel-Dwass test. All statistical tests were two sided, and a $p$ value $<0.05$ was considered to be statistically significant.

\section{Results}

Fyn is involved in the detachment of neuroblasts in the RMS To investigate the molecular mechanisms regulating the detachment of neuroblasts from chains, we first performed a chemical screen in in vitro cultures of V-SVZ-derived migrating neuroblasts. Of 287 target-known chemical inhibitors, we found that PP2, an inhibitor of Src family tyrosine kinases (Hanke et al., 1996), suppressed the detachment of neuroblasts in vitro. Timelapse imaging of chain-forming cultured neuroblasts revealed that the proportion of individually migrating neuroblasts was decreased by adding PP2, but not PP3, an inactive analog of PP2 (Fig. 1a,b). These results suggested that Src family tyrosine kinases are involved in the detachment of neuroblasts from chains.

The nonreceptor tyrosine kinases Src, Fyn, and Lck are targets of PP2 (Hanke et al., 1996). To examine whether these kinases are expressed in the V-SVZ-OB pathway, we performed WB using neonatal brain lysates. Src and Fyn, but not Lck, were expressed in the V-SVZ and OB (Fig. 1c). Since the detachment of neuroblasts was not affected by Src KD in vivo (see below), we focused on the Fyn expression and function. To examine the activation state of Fyn, we performed WB with an antiphosphorylated-Fyn (p-Fyn) antibody using tissue lysates from the pRMS and aRMS (Fig. 1d) collected by laser-capture microdissection. We found that the p-Fyn signal was lower in the pRMS than in the aRMS (Fig. 1d,e), suggesting that the Fyn activity in neuroblasts increases during their migration in the RMS.

$\leftarrow$

(Figure legend continued.) WT mice were stained for Dcx (red) and GFP (green) at 4 dpe. Arrowheads indicate $D c x{ }^{+} \mathrm{EmGFP}^{+}$neuroblasts $(n=334$ cells from 3 mice). $\boldsymbol{i}-\boldsymbol{k}$, Effect of Fyn $\mathrm{KD}$ on neuroblast migration into the $\mathrm{OB}$. $\boldsymbol{i}$, Proportion of EmGFP ${ }^{+}$cells in the $\mathrm{OB}$, aRMS, and pRMS at 4 dpe ( $n=3$ mice each). $\boldsymbol{k}$, Representative images of sagittal OB sections from control and Fyn KD mice stained for GFP at 6 dpe. The proportion of EmGFP ${ }^{+}$cells observed in the $\mathrm{OB}$ was significantly decreased by Fyn $\mathrm{KD}$ at 6 dpe $\left(j ; t_{(7)}=8.45, p=0.000064\right.$, unpaired $t$ test; control, $n=5$ mice; Fyn KD, $n=4$ mice). $I$, Proportion of EmGFP ${ }^{+}$cells in the $0 B$ of control and $\mathrm{Src} K \mathrm{KD}$ groups at 6 dpe ( $n=3$ mice each). $\boldsymbol{m}, \boldsymbol{n}$, Contact between EmGFP ${ }^{+}$cell somas. Representative images of the contact site between EmGFP ${ }^{+}$cell somas in the aRMS $(\boldsymbol{m})$. The percentage of EmGFP ${ }^{+}$cells making cell-cell contact at the cell body was significantly increased by Fyn KD $\left(\boldsymbol{n} ; t_{(4)}=-2.98, p=0.041\right.$, unpaired $t$ test; $n=3$ mice each). $\boldsymbol{o}-\boldsymbol{s}$, Effect of Fyn overexpression (OE) on neuroblast migration into the $\mathrm{OB}$. 0 , Proportion of $\mathrm{GFP}^{+}$cells in the $\mathrm{OB}$, aRMS, and pRMS at 4 dpe ( $n=4$ mice each). $\boldsymbol{p}, \boldsymbol{r}$, Representative images of sagittal $\mathrm{OB}(\boldsymbol{p})$ and pRMS $(\boldsymbol{r})$ sections from control and Fyn-overexpressing mice, stained for GFP at 6 dpe. The proportion of GFP ${ }^{+}$cells in the $\mathrm{OB}\left(\boldsymbol{q} ; t_{(8)}=-4.71, p=0.0015\right.$, unpaired $t$ test; $n=5$ mice each) and other cerebral regions neighboring the pRMS $\left(s ; F_{\text {group }(1,16)}=3.87, p_{\text {group }}=0.067\right.$, $F_{\text {region }(2,32)}=12.3, p_{\text {region }}=0.00011, F_{\text {group }} \times$ region $(2,32)=4.86, p_{\text {group }} \times$ region $=0.014$, two-way repeated-measures ANOVA; control vs Fyn OE in regions neighboring pRMS, $t_{(16)}=$ $3.19, p=0.0057$, unpaired $t$ test $; n=9$ mice each) was significantly increased by Fyn OE. Arrow indicates a GFP ${ }^{+}$cell observed in the cerebral region neighboring the pRMS $(\boldsymbol{r})$. oGCL, outer GCL; IPL, inner plexiform layer; $M C L$, mitral cell layer; $E P L$, external plexiform layer. Anterior side of the $O B$ is on the left $(\boldsymbol{k}, \boldsymbol{p})$. Scale bars: $\boldsymbol{a}, 20 \mu \mathrm{m} ; \boldsymbol{f}, 5 \mu \mathrm{m} ; \boldsymbol{h}, \boldsymbol{m}, 10 \mu \mathrm{m} ; \boldsymbol{k}, \boldsymbol{p}, \boldsymbol{r}, 50 \mu \mathrm{m} .{ }^{*} p<$ 0.05 , ${ }^{* * *} p<0.005$ (adjusted with Bonferroni correction in $s$ ). Error bars indicate mean \pm SEM.
To examine the expression and activation patterns of Fyn in the RMS more precisely, we performed quantitative immunohistochemical analyses for Fyn, p-Fyn, and Dcx, an immature neuroblast marker. Fyn expression was observed in all of the Dcx ${ }^{+}$ neuroblasts in the RMS ( $n=830$ cells from three mice). In addition, the p-Fyn intensity relative to Fyn intensity in the neuroblasts was higher in the aRMS than in the pRMS (Fig. $1 f, g$ ), suggesting that Fyn is activated in neuroblasts in the OB to promote their detachment from the RMS. These results raised the possibility that Fyn is involved in the detachment of neuroblasts from chains.

To investigate the role of Fyn in neuronal migration in the RMS and $\mathrm{OB}$, we performed a KD experiment. We introduced plasmids encoding both the KD sequences and EmGFP into $\mathrm{V}-\mathrm{SVZ}$ cells in P1 WT pups by in vivo electroporation, fixed them at 4 or 6 dpe, and analyzed the distribution of all the labeled cells observed in the RMS and OB. At 4 dpe, $98.6 \pm 0.7 \%$ of the labeled $\mathrm{EmGFP}^{+}$cells observed in the RMS were positive for Dcx (Fig. $1 h)$. In addition, the proportion of $\mathrm{EmGFP}^{+}$cells that reached the aRMS was not affected by Fyn KD (Fig. 1i; control cells, $61.2 \pm 3.9 \%$; Fyn-KD cells, $61.0 \pm 3.3 \%$ ). However, at 6 dpe, Fyn $\mathrm{KD}$ significantly decreased the proportion of EmGFP ${ }^{+}$cells observed in the granule cell layer (GCL) and glomerular layer (GL) of the OB (Fig. 1j,k; control cells, $36.6 \pm 0.8 \%$; Fyn-KD cells, $28.7 \pm 0.3 \%)$. In contrast, Src KD did not affect the distribution of EmGFP ${ }^{+}$cells in the GCL and GL at 6 dpe (Fig. 1 1 ; control, $32.5 \pm 1.6 \%$; Src KD, $33.9 \pm 0.4 \%$ ). Interestingly, in the aRMS, contacts between EmGFP ${ }^{+}$cell soma were observed at a higher frequency in the Fyn-KD group than in the control (Fig. 1m, $n$; control group, $23.0 \pm 2.3 \%$; Fyn-KD group, $34.1 \pm 2.9 \%$ ), although the EmGFP ${ }^{+}$cell density was similar in the two groups (control group, 97,200 $\pm 19,100$ cells $/ \mathrm{mm}^{3}$; Fyn-KD group, $102,400 \pm 19,600$ cells $\left./ \mathrm{mm}^{3}\right)$. Together, these results suggested that Fyn is involved in the neuroblast detachment in the RMS.

To determine whether Fyn promotes the migration of neuroblasts into the $\mathrm{OB}$, we performed a Fyn overexpression experiment. At 4 dpe, the proportion of $\mathrm{GFP}^{+}$cells that reached the aRMS was not affected by Fyn overexpression (Fig. 10 ; control, $60.9 \pm 3.6 \%$; Fyn overexpression, $65.4 \pm 2.0 \%$ ). However, at 6 dpe, Fyn overexpression significantly increased the proportion of $\mathrm{GFP}^{+}$cells observed in the OB layers (Fig. 1p,q; control, $31.9 \pm$ $1.6 \%$; Fyn overexpression, $40.7 \pm 1.0 \%$ ) and in other cerebral regions neighboring the pRMS (Fig. $1 d, r, s$; control, $1.1 \pm 0.3 \%$; Fyn overexpression, $3.0 \pm 0.5 \%)$. Together, these results suggested that Fyn overexpression promotes the detachment of neuroblasts from the RMS.

\section{Fyn regulates the radial migration of neuroblasts from the RMS toward the $\mathrm{OB}$}

To study the migratory behaviors of Fyn-KD cells, we introduced an EmGFP-tagged Fyn-KD plasmid and a DsRed-tagged control plasmid into the V-SVZ cells, and performed time-lapse imaging of these cells as they migrated in the RMS and OB of cultured brain slices at 5 dpe (Fig. 2, Movie 1). While $34.8 \pm 3.3 \%$ of the labeled cells migrated from the aRMS into the GCL during the imaging period in the control, only $9.7 \pm 2.8 \%$ of the Fyn-KD cells migrated (Fig. $2 a, b$; control cells, $34.8 \pm 3.3 \%$; Fyn-KD cells, $9.7 \pm 2.8 \%)$. During detachment, both the control and Fyn-KD cells could extend their leading process into the GCL (Fig. 2a). However, compared with the controls, the Fyn-KD cells could not smoothly migrate across the border between the aRMS and GCL, so they took a longer time to pass through the border (Fig. $2 a, c$; control cells, $140.5 \pm 6.2 \mathrm{~min}$; Fyn-KD cells, $205.8 \pm 25.2$ 


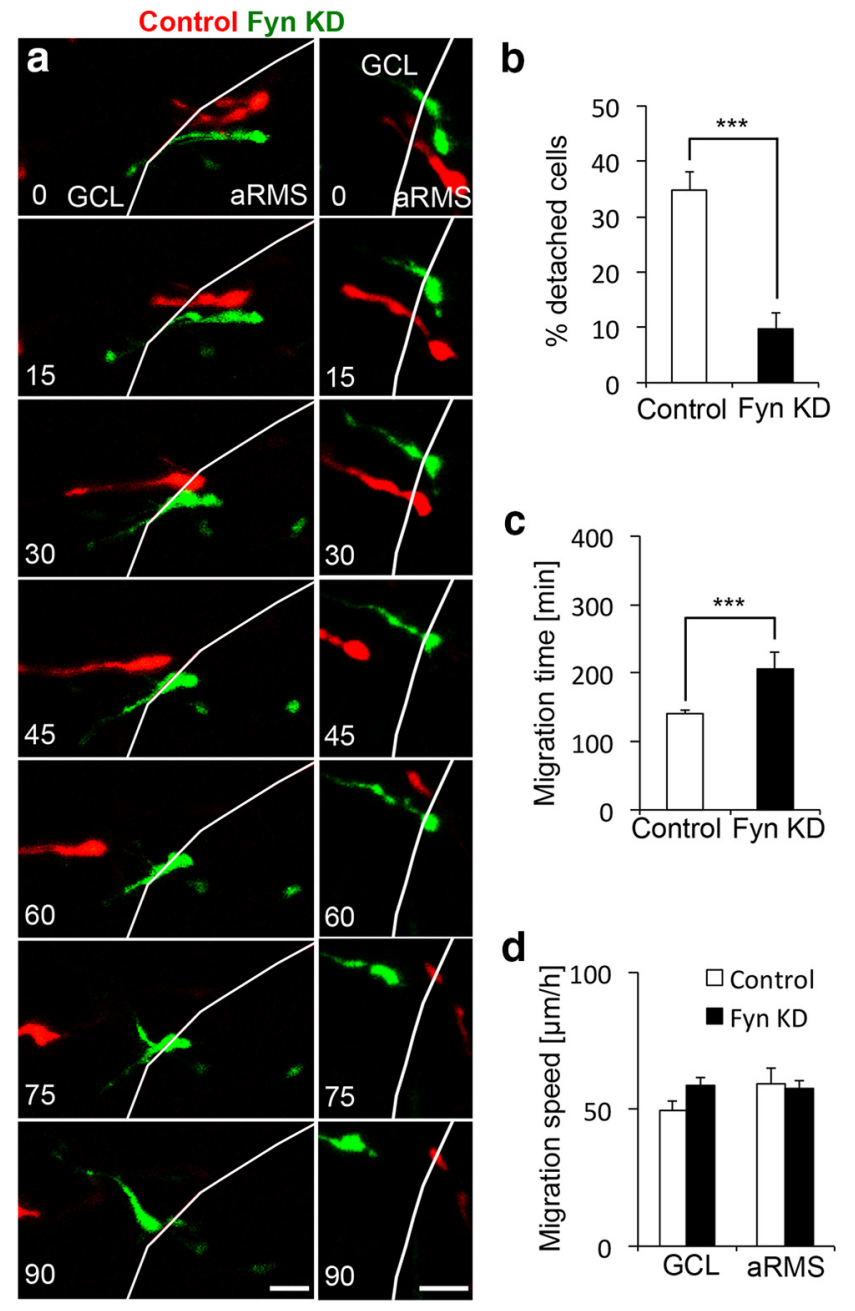

Figure 2. Fyn regulates the somal detachment of neuroblasts in the RMS. $\boldsymbol{a}-\boldsymbol{d}$, Effect of Fyn $\mathrm{KD}$ on the migratory behaviors of fluorescently labeled cells in cultured $\mathrm{OB}$-containing brain slices. Two examples of time-lapse images of a DsRed-expressing control cell (red) and an EmGFP-expressing Fyn KD cell (green) migrating in an OB-containing cultured brain slice $(\boldsymbol{a})$. White lines indicate the border between the aRMS and GCL. Compared with the control, Fyn KD significantly decreased the percentage of detached cells at the aRMS and GCL $\left(\boldsymbol{b} ; t_{(4)}=5.72\right.$, $p=0.0046$, unpaired $t$ test; $n=3$ independent cultures from three sections from three mice prepared on different days each for control and Fyn KD) and caused the cells to take a longer time to pass over the border between these two regions $\left(c ; t_{(31)}=-3.03, p=0.0050\right.$, unpaired $t$ test; control, $n=20$ cells; Fyn KD, $n=13$ cells; three independent cultures from three sections from three mice prepared on different days for each). Migration speed in the $\mathrm{GCL}$ and aRMS was similar in the control and Fyn KD groups ( $d$; control in $\mathrm{GCL}, n=30$ cells; Fyn KD in $\mathrm{GCL}, n=26$ cells; control in aRMS, $n=30$ cells; Fyn-KD in aRMS, $n=41$ cells; three independent cultures from three sections from three mice prepared on different days for each). Numbers indicate the number of minutes from the first imaging frame $(\boldsymbol{a}) .{ }^{* *} p<0.005$. Scale bars, $20 \mu \mathrm{m}$. Error bars indicate mean \pm SEM.

min). Fyn KD did not affect the migration speed in the aRMS or GCL (Fig. $2 d$; controls in GCL, $49.5 \pm 3.7 \mu \mathrm{m} / \mathrm{h}$; Fyn-KD cells in GCL, $58.6 \pm 5.5 \mu \mathrm{m} / \mathrm{h}$; controls in aRMS, $59.2 \pm 3.0 \mu \mathrm{m} / \mathrm{h}$; Fyn-KD cells in aRMS, $57.7 \pm 2.5 \mu \mathrm{m} / \mathrm{h}$ ). Together, these findings suggested that Fyn promotes the radial migration of neuroblasts from the RMS toward the GCL.

Disabled-1 is involved in the detachment of neuroblasts from chains in the RMS

Fyn is a nonreceptor tyrosine kinase that phosphorylates diverse substrates in response to extracellular stimuli. The binding of Reelin to its receptors including ApoER2 induces the phosphor-

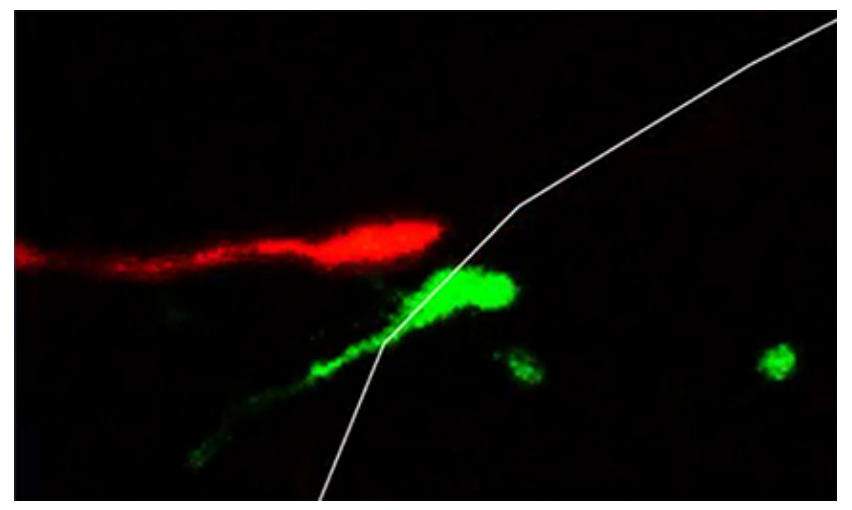

Movie 1. Time-lapse imaging of control and Fyn KD neuroblasts migrating in cultured $\mathrm{OB}$ slices. Two examples of time-lapse images of a DsRed-expressing control cell (red) and an EmGFP-expressing Fyn KD cell (green) migrating in an $\mathrm{OB}$-containing cultured brain slice. White lines indicate the border between the aRMS and GCL. Compared with the control, Fyn KD caused the cells to take a longer time to pass over the border between the aRMS and $\mathrm{GCL}$.

ylation of disabled-1 (Dab1) by Fyn (Arnaud et al., 2003). Immunohistochemical analysis using an anti-ApoER2 antibody revealed that the proportion of $\mathrm{Dcx}^{+}$neuroblasts that expressed ApoER2 was greater in the aRMS than in the GCL (Fig. $3 a$ ), suggesting that neuroblasts acquire their responsiveness to Reelin before they are detached from the chains.

Reelin is known to promote the detachment of migrating neuroblasts from chains (Hack et al., 2002; Simó et al., 2007; Courtès et al., 2011). In addition, previous in vitro studies suggested that Dab1 is involved in the Reelin-induced detachment of neuroblasts (Andrade et al., 2007; Simó et al., 2007; Blake et al., 2008). However, the function of Dab1 in neuroblast detachment in vivo has not been demonstrated. To examine the role of Dab1 in neuroblast detachment in the RMS, we performed a transplantation study using yotari mice (Fig. $3 b-h$ ), in which part of the Dab1 gene is deleted and no functional Dab1 protein is expressed (Sheldon et al., 1997; Onoue et al., 2014). Since the vast majority of V-SVZ-derived cells are of the GABAergic neuronal lineage (Kempermann, 2011), we used GAD67-EGFP mice, in which the migrating GABAergic neuroblasts are labeled with GFP until they mature in the OB (Wu et al., 2011; Plachez and Puche, 2012; Fig. $3 c)$. V-SVZ cells dissected from P2-P4 GAD67-EGFP;Dab1 $1^{\text {yot/+ }}$ or GAD67-EGFP;Dab1 $1^{\text {yot/yot }}$ mice were transplanted into the V-SVZ of P1 WT mice, and the behaviors of these cells in the RMS and $\mathrm{OB}$ were analyzed (Fig. $3 b-h$ ). At $6-7 \mathrm{~d}$ post-transplantation $(\mathrm{dpt})$, slice culture imaging revealed disrupted migration of the $\mathrm{GFP}^{+} \mathrm{Dabl}^{\text {yot/yot }}$ cells from the aRMS into the GCL (Fig. 3d,e; Dab1 ${ }^{+/ y o t}$ cells, $90.4 \pm 6.3 \mathrm{~min}$; Dab1 $1^{\text {yot } / y o t}$ cells, $170.3 \pm 20.8$ min), suggesting that Dab1 is involved in the detachment of $\mathrm{GFP}^{+}$cells from the RMS. Furthermore, the disrupted detachment of $\mathrm{GFP}^{+}$cells by the Dab1 mutation caused these cells to accumulate in the deep layer of the OB [Fig. $3 f-h ; D a b 1^{y o t /+}$ in the inner GCL (iGCL), $34.7 \pm 2.2 \%$; Dabl $1^{\text {yot } / y o t}$ in iGCL, $59.3 \pm$ 2.4\%]. Together, these results suggested that, similar to Fyn, Dab1 is involved in the detachment of neuroblasts in the RMS.

Reelin-Dab1 signaling decreases the adherens junction-like structures between neuroblasts

To observe the involvement of Fyn in neuroblast detachment in vitro, we introduced EmGFP-tagged Fyn-KD plasmids into cultured neuroblasts and added Reelin to the culture medium. At $3 \mathrm{~d}$ 
a

a ApoER2

Dcx

GFAP Merge
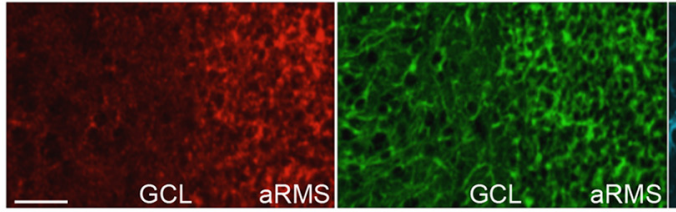

V-SVZ dissection

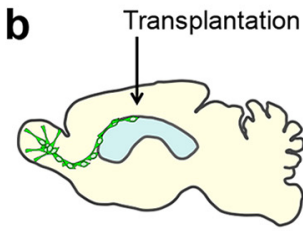

Wild-type

C $_{\text {GAD67-EGFP; }}$ Dab1yot/t
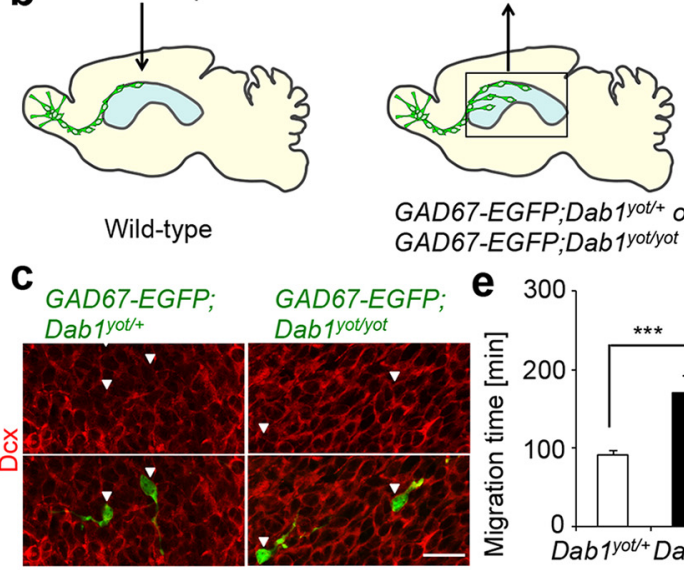

GAD67-EGFP:Dab1yot+ or GAD67-EGFP;Dab1yotyot
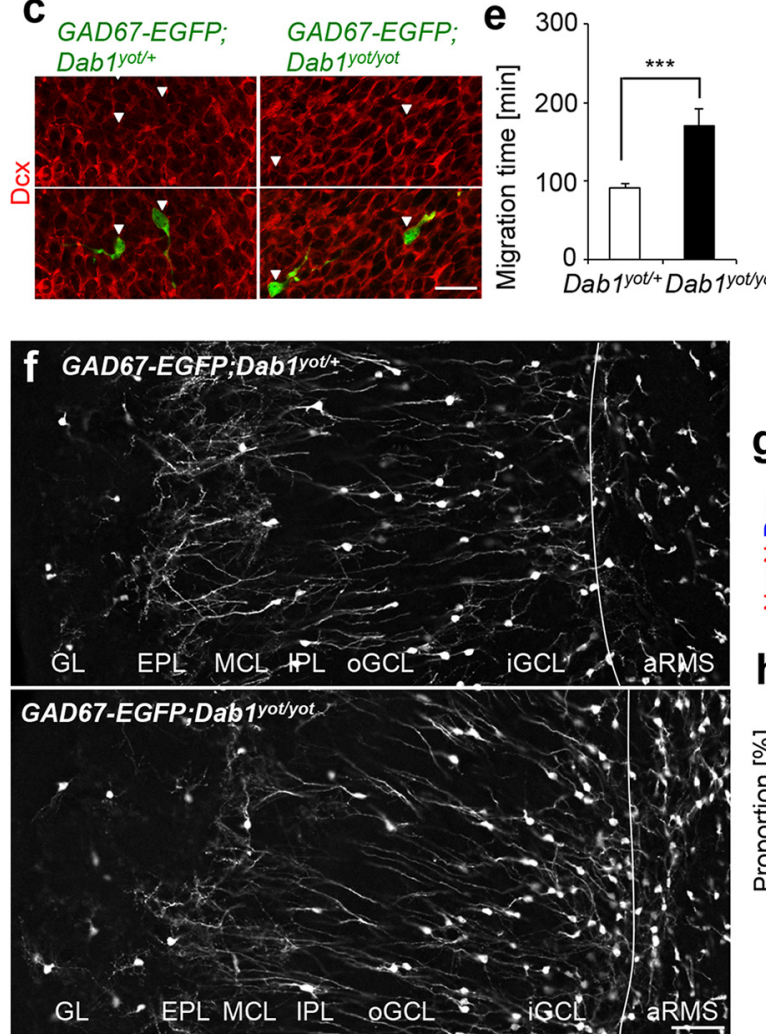
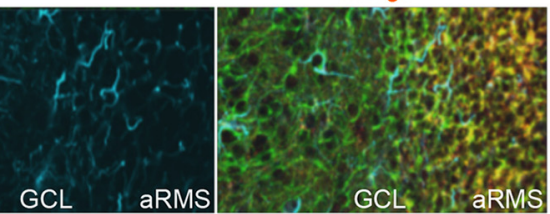

d GAD67-EGFP;
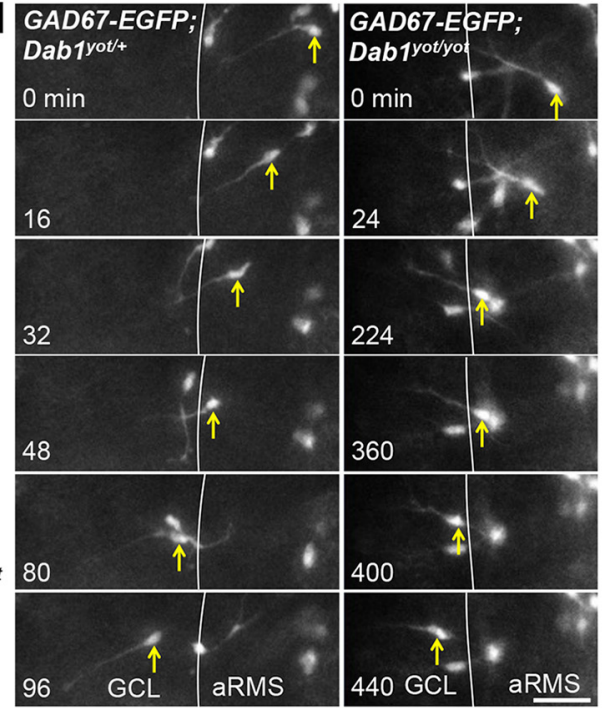

9 GAD67-EGFP;Dab1yot+ GAD67-EGFP;Dab1yotyot
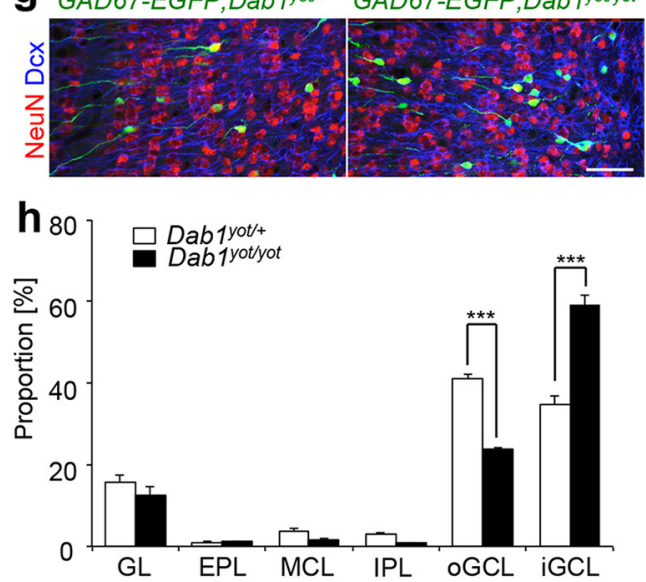

Figure 3. Dab1 is involved in the detachment of neuroblasts in the RMS. $\boldsymbol{a}$, ApoER2 expression in the OB. Coronal OB sections from P14 WT mice were stained for ApoER2 (red), Dcx (green), and GFAP (blue). ApoER2 was expressed in Dcx ${ }^{+}$neuroblasts (aRMS, $99.9 \pm 0.1 \% ; G C L, 10.3 \pm 1.6 \% ; n=3$ mice; $t_{(4)}=54.5, p=0.00000068$, unpaired $t$ test) but not in GFAP ${ }^{+}$astrocytes. $\boldsymbol{b}$, Experimental scheme. $c$, Representative images of sagittal RMS sections stained for Dcx (red) and GFP (green) at 5 dpt. All of the GFP ${ }^{+}$cells expressed Dcx (arrowheads; Dab $7^{\text {yot/ } /}, n=164$ cells from three mice; Dab $7^{\text {yot } y o t}, n=227$ cells from three mice). $\boldsymbol{d}, \boldsymbol{e}$, Effect of Dab1 deficiency on the migratory behaviors of neuroblasts in cultured OB slices at 7 dpt. Time-lapse images of

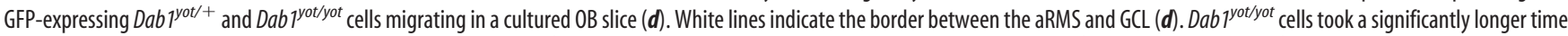
to pass through the border between the aRMS and GCL than Dab7 $7^{\text {yot/ } /}$ cells $\left(e ; t_{(53)}=-4.42, p=0.000050\right.$, unpaired $t$ test; Dab $7^{\text {yot } /+}, n=34$ cells; Dab $7^{\text {yot } / y o t}, n=21$ cells; three independent cultures from three sections from three mice for each). $\boldsymbol{f}$ - $\boldsymbol{h}$, Distribution of transplanted GFP ${ }^{+}$Dab $7^{\text {yot } /+}$ and Dab $7^{\text {yot/yot }}$ cells in the $0 \mathrm{~B}$ at 14 dpt. Representative images of coronal $0 B$ sections stained for GFP ( $\boldsymbol{f}$, white; $\boldsymbol{g}$, green), NeuN ( $\boldsymbol{g}$, red), and Dcx ( $\boldsymbol{g}$, blue). Most of the GFP ${ }^{+}$cells expressed NeuN ( $\boldsymbol{g} ;$ Dab $7^{\text {yot/ }+}, 74.5 \pm 2.9 \% ;$ Dab $7^{\text {yot/yot }}, 79.7 \pm 3.4 \% ; n=3$ mice each). Compared with the Dab7 $7^{\text {yot/ + }}$ group, more GFP ${ }^{+}$cells accumulated in the iGCL in the Dab7 $7^{\text {yot/yot }}$ group ( $h$; Dab $7^{\text {yot/ + }}$ in GL, $15.6 \pm 1.9 \%$; Dab $7^{\text {yot/yot }}$ in GL, $12.6 \pm 2.0 \%$; Dab $7^{\text {yot/ + }}$ in EPL, $0.9 \pm 0.2 \%$;

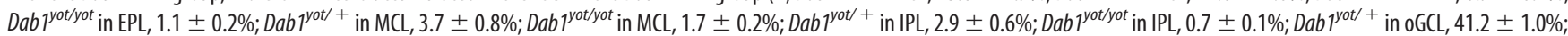
Dab7 ${ }^{\text {yot } / y o t}$ in $0 G C L, 23.6 \pm 0.6 \% ; D a b 7^{y o t /+}$ in iGCL, $34.7 \pm 2.2 \%$; Dab7 $7^{\text {yot } y o t}$ in iGCL, $59.3 \pm 2.4 \% ; F_{\text {group }(1,8)}=0.105, p_{\text {group }}=0.754, F_{\text {region }(5,40)}=353, p_{\text {region }}=5.8 \times 10^{-32}$,

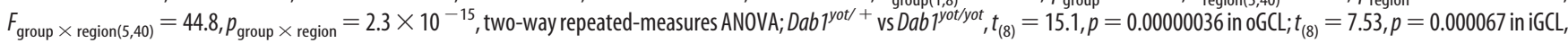
unpaired $t$ test; $n=5$ mice each). oGCL, Outer GCL; IPL, internal plexiform layer; MCL, mitral cell layer; EPL, external plexiform layer. ${ }^{* * *} p<0.005 . S$ Scale bars: $\boldsymbol{a}, \boldsymbol{f}, \boldsymbol{g}, 50 \mu \mathrm{m} ; \boldsymbol{c}, \boldsymbol{d}, 20 \mu \mathrm{m}$. Error bars indicate mean \pm SEM.

in vitro, the proportion of EmGFP ${ }^{+}$cells was significantly increased in the Reelin-supplemented group (Fig. $4 a$ ), as reported previously (Hack et al., 2002; Simó et al., 2007; Courtès et al., 2011). Moreover, Fyn KD significantly decreased the proportion of individual (nonattached) EmGFP ${ }^{+}$cells in both the control and the Reln-supplemented culture conditions (Fig. $4 a$ ), which is consistent with our proposal that Fyn contributes to the cell-cell detachment of neuroblasts.

p120-catenin, an important component of adherens junctions (AJs), binds to the intracellular domain of cadherin, and suppresses its endocytosis (Ishiyama et al., 2010; Nanes et al., 2012). Fyn phosphorylates p120-catenin to induce its dissociation from 
a

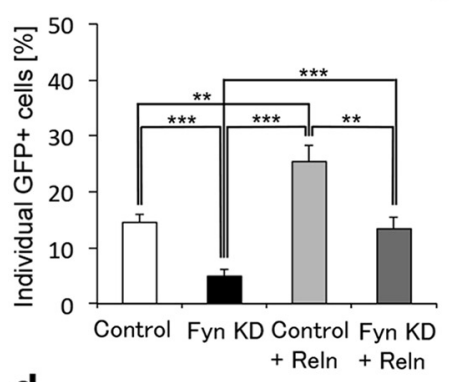

d

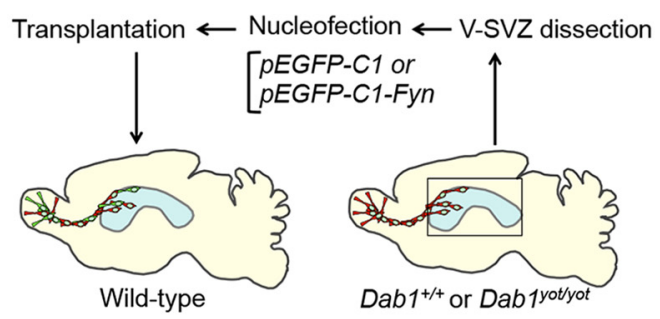

f

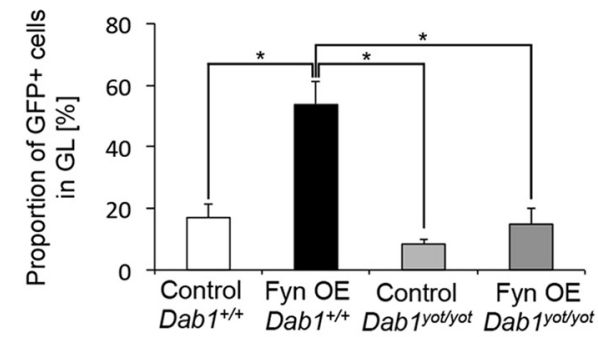

g

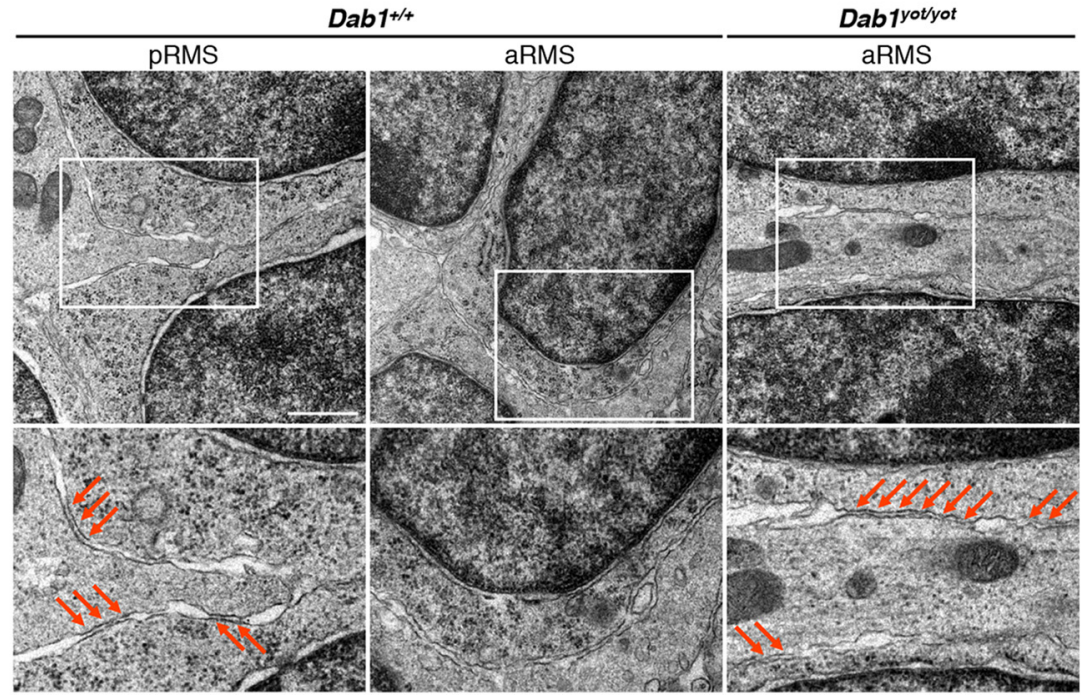

Figure 4. Reelin-Dab1 signaling decreases the adherens junction-like structures between neuroblasts. $\boldsymbol{a}$, Effect of Fyn KD on the detachment of cultured neuroblasts. The proportion of total GFP-labeled cells that were individual (nonattached) GFP ${ }^{+}$cells was significantly decreased by Fyn KD in both the control and Reelin-supplemented cultures (Control, $14.5 \pm 1.3 \%$; Fyn KD, $4.9 \pm$ 1.1\%; Control + Reln, 23.9 \pm 2.9\%; Fyn KD + Reln, $14.7 \pm 1.4 \% ; \chi^{2}(3)=36.7, p=0.000000052$, Kruskal-Wallis test; Control vs Fyn KD, $t(\infty)=4.06, p=0.00028$; Control + Reln vs Fyn KD + Reln, $t(\infty)=3.26, p=0.0062$; Control vs Reln, $t(\infty)=3.21$, $p=0.0072$; Fyn KD vs Reln, $t(\infty)=4.92, p=0.0000051$; Fyn KD vs Fyn KD + Reln, $t(\infty)=3.44, p=0.0033$, Steel-Dwass test; $n=4$ independent cultures each prepared on different days). $\boldsymbol{b}, \boldsymbol{c}$, Effect of Fyn KD on the p120-catenin ${ }^{+}$fluorescence intensity at cell-cell contact sites. Representative images of cultured V-SVZ-derived cells stained for GFP (Control and Fyn KD, green) and p120-catenin (red; $\boldsymbol{b})$. The relative $\mathrm{p} 120$-catenin ${ }^{+}$fluorescence intensity at cell-cell contact regions was significantly increased by Fyn KD ( $c$; $t_{(33)}=2.80, p=0.0084$, unpaired $t$ test; control, $n=19$ cells; Fyn KD, $n=16$ cells; three independent cultures of each, prepared on different days). $\boldsymbol{d}-\boldsymbol{f}$, Effect of Dab1 deficiency on the promotion of neuroblast migration toward the GL by Fyn overexpression (OE). $\boldsymbol{d}$, Experimental scheme. $\boldsymbol{e}$, Representative images of coronal OB sections stained for GFP at $14 \mathrm{dpt}$. Arrows indicate $\mathrm{GFP}^{+}$cells that reached the GL. The proportion of GFP ${ }^{+}$cells observed in the GL was significantly increased by Fyn $0 \mathrm{E}$ in

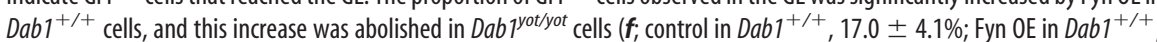

cadherin, leading to cadherin endocytosis (Piedra et al., 2003). Since Fyn KD increased the adhesion between neuroblasts, we hypothesized that Fyn KD would promote the accumulation of p120-catenin at the contact regions between neuroblasts. To test this possibility, we quantitatively analyzed the p120catenin ${ }^{+}$immunofluorescence intensity at the contact sites between cultured neuroblasts. We found that this intensity was significantly increased by Fyn KD (Fig. $4 b, c$; control cells, $1.9 \pm 0.1$; Fyn-KD cells, $2.5 \pm 0.2$ ), suggesting that Fyn decreases the amount of cadherin-catenin complex between neuroblasts in vitro.

To investigate the relationship between Reelin-Dab1 signaling and Fyn in neuroblast detachment and migration in the OB, we introduced Fyn overexpression plasmids into $\mathrm{Dab1}^{+/+}$or Dab1 $1^{\text {yot/yot }}$ cells dissected from the V-SVZ, and transplanted these cells into the V-SVZ of WT mice (Fig. 4d). At 14 dpt, Fyn overexpression significantly increased the proportion of $\mathrm{GFP}^{+}$cells that reached the GL (Fig. 4e,f), suggesting that Fyn overexpression promoted neuroblast migration toward the GL. Notably, this effect of Fyn overexpression was abolished by Dab1 deficiency (Fig. 4e,f), suggesting that Dab1 is involved in the Fyn-induced promotion of neuroblast detachment and migration in the OB.

Chain-forming neuroblasts in the RMS attach tightly to their neighboring neuroblasts by AJ-like structures (Doetsch et al., 1997). To examine whether Dab1 affects the AJ-like structures between chain-forming neuroblasts in vivo, we observed these cells in WT and yotari mice by electron microscopy. WT neuroblasts showed AJ-like structures in the pRMS that were not observed in the aRMS, suggesting that detaching neuro-

$\leftarrow$

$53.7 \pm 7.5 \%$; control in Dab $1^{\text {yot } / y o t}, 8.4 \pm 1.5 \%$; Fyn $\mathrm{OE}$ in Dabi ${ }^{\text {yot } y o t}, 14.8 \pm 4.9 \% ; \chi^{2}(3)=13.3, p=0.0041$, Kruskal-Wallis test; control vs Fyn $\mathrm{OE}$ in $\mathrm{Dab} 1^{+/+}, t(\infty)=$ $2.61, p=0.045 ;$ Fyn 0 E in Dab1 $1^{+/+}$vs Dab $1^{\text {yot } / y o t}, t(\infty)=$ $2.61, p=0.045$; Fyn OE in Dab1 ${ }^{+/+}$vs control in Dab $7^{\text {yot } / \text { yot }}$, $t(\infty)=2.93, p=0.018$; Steel-Dwass test; Control in $D a b 1^{+/+}, n=5$ mice; Fyn OE in Dab1 $1^{+/+}, n=5$ mice; Control in Dab7 yot/yot,$n=8$ mice; Fyn OE in Dab7 $7^{\text {yot } / y o t}, n=5$ mice). $\boldsymbol{g}$, Effect of Dab1 inhibition on the AJ-like structures of chain-forming migrating neuroblasts. Representative transmission electron microscopic images of neuroblasts from $\mathrm{Dab}^{+/+}$and Dab $7^{\text {yot/yot }}$ mice. Arrows indicate AJ-like structures. In Dab7 $7^{\text {yot } / y o t}$ mice, the neuroblasts sustained AJ-like structures even in the aRMS. EPL, External plexiform layer. Scale bars: $\boldsymbol{b}, 2 \mu \mathrm{m} ; \boldsymbol{e}, 100 \mu \mathrm{m} ; \boldsymbol{g}, 1 \mu \mathrm{m} .{ }^{*} p<0.05,{ }^{* *} p<$ $0.01,{ }^{* * *} p<0.005$. Error bars indicate mean \pm SEM. 
blasts lose their AJ-like structures (Fig. 4g; $\left.\mathrm{Dabl}^{+/+}\right)$. In contrast, Dab1 $1^{\text {yot/yot }}$ neuroblasts had AJ-like structures even in the aRMS (Fig. $4 g$; Dabl $1^{\text {yot } / y o t}$ ), suggesting that Dab1 promotes the downregulation of AJ-like structures between neuroblasts. Together, these results suggest that Reelin-Dab1 signaling decreases the AJ-like structures between neuroblasts during the detachment process.

\section{$\mathrm{N}$-cadherin is involved in the Fyn knockdown-induced suppression of neuroblast detachment from the RMS} $\mathrm{N}$-cadherin is expressed in chain-forming migrating neuroblasts in the RMS (Yagita et al., 2009) and is required for their chain migration (Porlan et al., 2014). Moreover, $\mathrm{N}$-cadherin is the central component of the AJs (Peglion et al., 2014). To investigate whether Fyn regulates N-cadherinmediated cell adhesion, we analyzed the adhesion and migration of cultured neuroblasts on an N-cadherin-Fc-coated dish (Yue et al., 2010; Haque et al., 2012, 2015; Jinnou et al., 2018). Fyn KD significantly increased the p120-catenin ${ }^{+}$immunofluorescence intensity (Fig. $5 a-c$ ), and decreased the migration speed of these neuroblasts (Fig. $5 d$; control neuroblasts, $57.4 \pm 3.4 \mu \mathrm{m} / \mathrm{h}$; Fyn-KD neuroblasts, $46.6 \pm 4.1 \mu \mathrm{m} / \mathrm{h}$ ), suggesting that Fyn regulates the $\mathrm{N}$-cadherin-dependent cell adhesion to promote efficient neuronal migration.

Last, to examine whether $\mathrm{N}$-cadherin is involved in the Fyn KD-induced suppression of neuroblast detachment (Fig. $1 j, k)$, we performed Fyn and N-cadherin double-KD experiments (Fig. $5 e-g$ ). EmGFP-tagged Fyn-KD plasmids and tdTomato-tagged N-cadherin-KD plasmids were introduced into V-SVZ cells by in vivo electroporation. At 6 dpe, although the $\mathrm{N}$-cadherin $\mathrm{KD}$ alone did not affect migration into the RMS and $\mathrm{OB}$ (Fig. $5 e, f$; control plasmids, $29.0 \pm 3.3 \%$; $N$ cadherin-KD plasmids, $26.1 \pm 7.7 \%$ ), $\mathrm{N}$-cadherin KD rescued the Fyn KDinduced suppression of the detachment of EmGFP $^{+}$tdTomato $^{+}$cells, in the double$\mathrm{KD}$ condition (Fig. $5 e, g$; Fyn $\mathrm{KD}+$ control, $30.0 \pm 1.7 \%$; Fyn KD + N-cadherin KD, $34.9 \pm 1.3 \%$ ). Together, these results suggested that $\mathrm{N}$-cadherin is involved in the Fyn KD-induced suppression of neuroblast detachment from the RMS.

\section{Discussion}

This study clarified the cellular and molecular mechanisms for the cell-cell detachment of V-SVZ-derived neuroblasts from chains in the postnatal OB. By combining a chemical screen with loss-of-function and gain-of-function experiments in vivo, we identified Fyn as an intracellular regulator of the neuroblast detach-
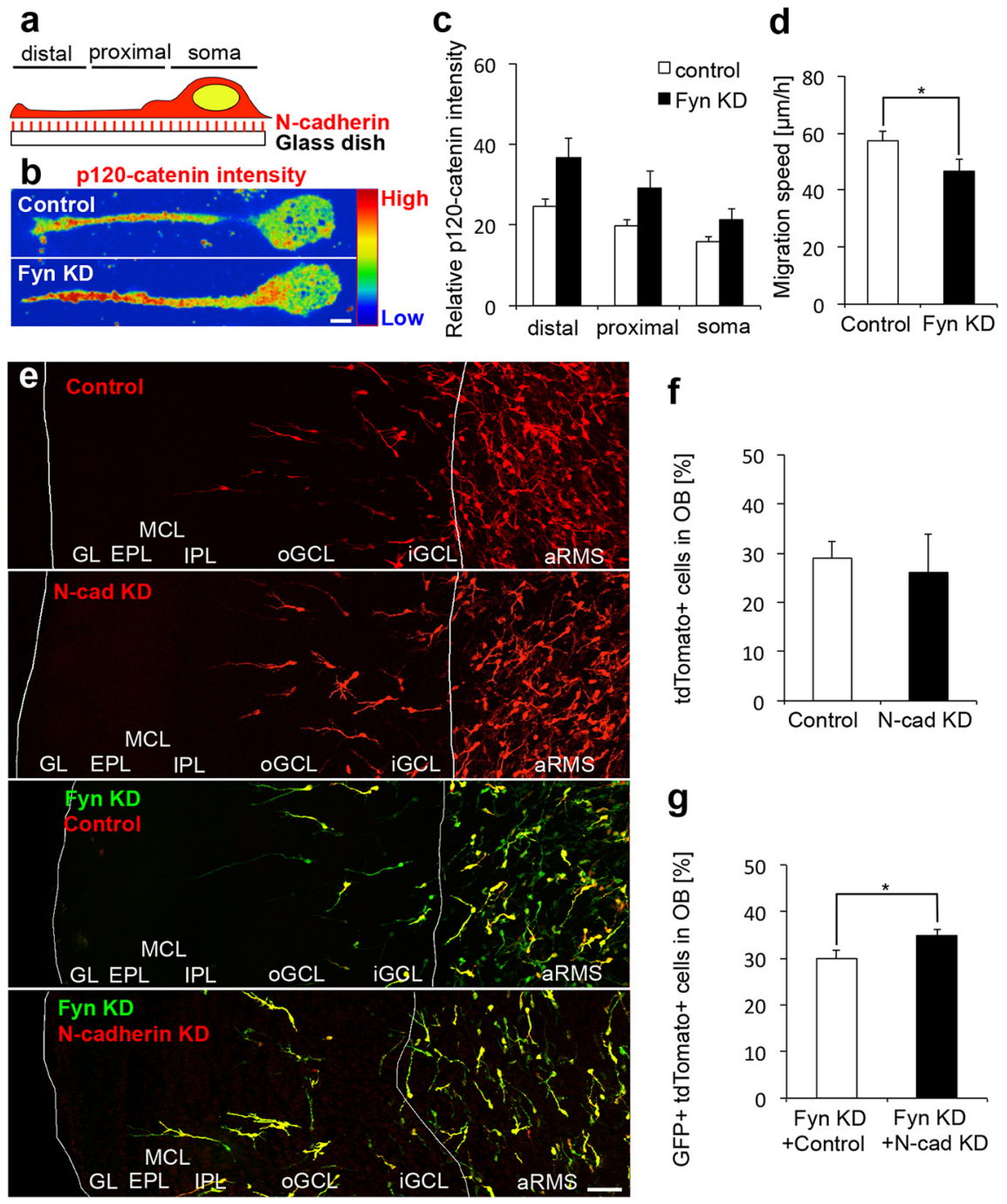

Figure 5. N-cadherin is involved in the Fyn knockdown-induced suppression of neuroblast detachment from the RMS. $\boldsymbol{a}-\boldsymbol{d}$ Effect of Fyn KD on the adhesion and migration of cultured neuroblasts on an $\mathrm{N}$-cadherin-Fc-coated dish. Representative images of the relative intensity of p120-catenin ${ }^{+}$signals ( $\boldsymbol{b}$, pseudocolors) at the attaching surface of control and Fyn KD cells on an $\mathrm{N}$-cadherin-Fc-coated dish $(\boldsymbol{a}, \boldsymbol{b})$. Compared with the control, Fyn KD significantly increased the relative $\mathrm{p} 120$-catenin ${ }^{+}$intensity at the leading process and soma $\left(\boldsymbol{c} ; F_{\text {group }(1,92)}=5.00, p_{\text {group }}=0.028, F_{\text {region }(2,184)}=41.8, p_{\text {region }}=1.1 \times 10^{-15}\right.$,

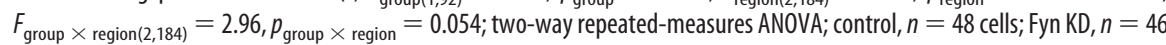
cells; four independent cultures of each, prepared on different days), and decreased the migration speed of neuroblasts on the $\mathrm{N}$-cadherin-Fc-coated dish $\left(\boldsymbol{d} ; t_{(147)}=2.05, p=0.043\right.$, unpaired $t$ test; control, $n=80$ cells; Fyn KD, $n=69$ cells; three independent cultures of each, prepared on different days). $\boldsymbol{e}-\boldsymbol{g}$, Effect of Fyn and N-cadherin double-KD on neuronal migration into the $\mathrm{OB}$. Representative images of sagittal $\mathrm{OB}$ sections prepared from Fyn and N-cadherin double-KD brain, stained for GFP (green) and DsRed (red; $\boldsymbol{e})$. The proportion of tdTomato ${ }^{+}$cells observed in the OB was not affected by N-cadherin KD alone $(\boldsymbol{e}, \boldsymbol{f} ;$ control, $n=5$ mice; N-cadherin KD, $n=3$ mice), but it was significantly increased by Fyn and N-cadherin double-KD compared with Fyn $\mathrm{KD}\left(\boldsymbol{e}, \boldsymbol{g} ; t_{(9)}=2.33, p=0.045\right.$, unpaired $t$ test; Fyn KD + control, $n=5$; Fyn KD + N-cadherin KD, $n=6$ mice). oGCL, Outer GCL; IPL, inner plexiform layer; $M C L$, mitral cell layer; $E P L$, external plexiform layer. Anterior side of the $O B$ is on the left (e). Scale bars: $\boldsymbol{b}, 5 \mu \mathrm{m} ; \boldsymbol{e}, 50 \mu \mathrm{m} .{ }^{*} p<0.05$. Error bars indicate mean \pm SEM.

ment from chains in the postnatal OB. We found that Fyn and Dab1 decrease the cell-cell adhesion between chain-forming neuroblasts, which involves AJ-like structures. Transplantation experiments indicated that Dab1 is involved in the Fyn-induced promotion of neuroblast detachment, suggesting that Fyn interacts with Reelin-Dab1 signaling to control neuroblast detachment in the OB. Our findings suggest that Fyn-mediated regulation of the cell-cell adhesion of neuroblasts is critical for their detachment from chains in the postnatal brain.

Reelin, Tenascin-R, and PK2 induce the detachment of neuroblasts from chains in the OB (Hack et al., 2002; Saghatelyan et 
al., 2004; Ng et al., 2005). In addition, the downregulation of S1P1 promotes neuroblast detachment in the OB (Alfonso et al., 2015). Contactin, a glypiated neuronal cell adhesion molecule that is an endogenous receptor for Tenascin- $\mathrm{R}$, regulates the activity and intracellular distribution of Fyn (Zisch et al., 1995). Thus, it is possible that Fyn mediates the promotion of neuroblast detachment by Tenascin-R (Saghatelyan et al., 2004). Interestingly, the expressions of Reelin and Tenascin-R in the OB are regulated by olfactory activity (Saghatelyan et al., 2004; Okuyama-Yamamoto et al., 2005), suggesting that Fyn mediates the activity-dependent promotion of neuroblast detachment from the RMS. Further studies on the relationships between Fyn and other detachment signals, including PK2 and the downregulation of S1P1, will be important to improve our understanding of the mechanisms regulating neuroblast detachment in the postnatal brain.

In the embryonic cortex, the Reelin-Dab1 pathway temporally regulates cell adhesion (Ballif et al., 2004; Franco et al., 2011; Matsunaga et al., 2017) and governs radial neuronal migration, which is regulated by Fyn (Jossin et al., 2003; Kuo et al., 2005; Nishimura et al., 2010). In the postnatal brain, Dab1 is involved in neuroblast migration in the RMS (Andrade et al., 2007; Blake et al., 2008). Although we could not detect any migration defects of transplanted Dab1 $1^{\text {yot } / y o t}$ neuroblasts in the RMS, it is possible that these cells were oriented passively by their surrounding $D a b 1^{+/+}$neuroblasts migrating toward the OB. We found that the Fyn overexpression-induced promotion of neuroblast detachment and migration in the OB depended on Dab1, suggesting that Reelin-Dab1 signaling and Fyn are functionally linked in the postnatal $\mathrm{OB}$, similar to their relationship in the embryonic brain.

The transition from tangential to radial migration is a dramatic change for the chain-forming neuroblasts (Alfonso et al., 2015). However, the cellular mechanisms regulating the cell-cell detachment process of neuroblasts from the RMS have been unclear. Our live imaging of neuroblasts migrating in acute brain slices revealed that during the detachment process, the neuroblasts maintained their migration speed and showed typical saltatory movement, in which they first extended their leading process into the GCL and subsequently moved their soma, as previously reported for neuroblasts in the RMS (Schaar and McConnell, 2005; Ota et al., 2014). Their efficient detachment prevented the chain-forming neuroblasts from stacking at the border between the RMS and $\mathrm{OB}$, and enabled them to move continuously and efficiently into the OB. We also found that Fyn KD and Dab1 $1^{\text {yot/yot }}$ neuroblasts could not downregulate cell adhesion or smoothly detach from the RMS. These results suggested that the downregulation of cell adhesion is a critical process in neuroblast detachment from the RMS, and that it is regulated by Fyn.

The AJ-like structure is a specialized adhesion complex observed between chain-forming neuroblasts in the adult RMS (Doetsch et al., 1997). Although several adhesion molecules are involved in the migration of V-SVZ-derived neuroblasts, including N-cadherin, $\beta 1$-integrin, and polysialylated NCAM (Tomasiewicz et al., 1993; Cremer et al., 1994; Ono et al., 1994; Chazal et al., 2000; Emsley and Hagg, 2003; Belvindrah et al., 2007; Porlan et al., 2014; Alfonso et al., 2015; Fujioka et al., 2017; Jinnou et al., 2018), the mechanism controlling the AJ-like structures in chain migration is still unknown. Since the AJs in epithelial cells consist of cadherins and adaptor proteins such as p120-catenin (Ishiyama et al., 2010), these molecules could also constitute the AJ-like structures in chain-forming neuroblasts. Our transplantation experiments indicated that Dab1 is involved in the Fyn-induced promotion of neuroblast detachment, suggesting that Fyn interacts with Reelin-Dab1 signaling to control neuroblast detachment in the OB. These results are consistent with previous studies showing that Fyn is localized to the inner surface of the cell membrane by p120-catenin and cadherin signaling (Piedra et al., 2003; Ishiyama et al., 2010), and phosphorylates Dab1 (Arnaud et al., 2003). Alternatively, Fyn may directly phosphorylate p120-catenin, thereby promoting cadherin endocytosis by releasing p120-catenin from the intracellular domain of cadherin (Ishiyama et al., 2010), leading to neuroblast detachment. In any case, our results collectively suggest that mechanisms involving Fyn and Reelin-Dab1 signaling decrease the AJ-like structures in neuroblasts to promote the efficient detachment of neuroblasts from chains in the OB. In conclusion, this study proposes that Fyn-mediated regulation of cell adhesion between neuroblasts governs their detachment from chains, thereby affecting neuronal migration and positioning in the postnatal $\mathrm{OB}$.

\section{References}

Alfonso J, Penkert H, Duman C, Zuccotti A, Monyer H (2015) Downregulation of sphingosine 1-phosphate receptor 1 promotes the switch from tangential to radial migration in the OB. J Neurosci 35:13659-13672. CrossRef Medline

Andrade N, Komnenovic V, Blake SM, Jossin Y, Howell B, Goffinet A, Schneider WJ, Nimpf J (2007) ApoER2/VLDL receptor and Dab1 in the rostral migratory stream function in postnatal neuronal migration independently of reelin. Proc Natl Acad Sci U S A 104:8508-8513. CrossRef Medline

Arnaud L, Ballif BA, Förster E, Cooper JA (2003) Fyn tyrosine kinase is a critical regulator of disabled-1 during brain development. Curr Biol 13: 9-17. CrossRef Medline

Ballif BA, Arnaud L, Arthur WT, Guris D, Imamoto A, Cooper JA (2004) Activation of a Dab1/CrkL/C3G/Rap1 pathway in reelin-stimulated neurons. Curr Biol 14:606-610. CrossRef Medline

Belvindrah R, Hankel S, Walker J, Patton BL, Müller U (2007) $\beta 1$ integrins control the formation of cell chains in the adult rostral migratory stream. J Neurosci 27:2704-2717. CrossRef Medline

Blake SM, Strasser V, Andrade N, Duit S, Hofbauer R, Schneider WJ, Nimpf J (2008) Thrombospondin-1 binds to ApoER2 and VLDL receptor and functions in postnatal neuronal migration. EMBO J 27:3069-3080. CrossRef Medline

Breton-Provencher V, Lemasson M, Peralta MR 3rd, Saghatelyan A (2009) Interneurons produced in adulthood are required for the normal functioning of the olfactory bulb network and for the execution of selected olfactory behaviors. J Neurosci 29:15245-15257. CrossRef Medline

Chazal G, Durbec P, Jankovski A, Rougon G, Cremer H (2000) Consequences of neural cell adhesion molecule deficiency on cell migration in the rostral migratory stream of the mouse. J Neurosci 20:1446-1457. CrossRef Medline

Courtès S, Vernerey J, Pujadas L, Magalon K, Cremer H, Soriano E, Durbec P, Cayre M (2011) Reelin controls progenitor cell migration in the healthy and pathological adult mouse brain. PLoS One 6:e20430. CrossRef Medline

Cremer H, Lange R, Christoph A, Plomann M, Vopper G, Roes J, Brown R, Baldwin S, Kraemer P, Scheff S (1994) Inactivation of the N-CAM gene in mice results in size reduction of the olfactory bulb and deficits in spatial learning. Nature 367:455-459. CrossRef Medline

D’Arcangelo G, Nakajima K, Miyata T, Ogawa M, Mikoshiba K, Curran T (1997) Reelin is a secreted glycoprotein recognized by the CR-50 monoclonal antibody. J Neurosci 17:23-31. CrossRef Medline

Doetsch F, García-Verdugo JM, Alvarez-Buylla A (1997) Cellular composition and three-dimensional organization of the subventricular germinal zone in the adult mammalian brain. J Neurosci 17:5046-5061. CrossRef Medline

Doetsch F, Caillé I, Lim DA, García-Verdugo JM, Alvarez-Buylla A (1999) Subventricular zone astrocytes are neural stem cells in the adult mammalian brain. Cell 97:703-716. CrossRef Medline

Emsley JG, Hagg T (2003) alpha6betal integrin directs migration of neuro- 
nal precursors in adult mouse forebrain. Exp Neurol 183:273-285. CrossRef Medline

Famulski JK, Trivedi N, Howell D, Yang Y, Tong Y, Gilbertson R, Solecki DJ (2010) Siah regulation of Pard3A controls neuronal cell adhesion during germinal zone exit. Science 330:1834-1838. CrossRef Medline

Franco SJ, Martinez-Garay I, Gil-Sanz C, Harkins-Perry SR, Müller U (2011) Reelin regulates cadherin function via Dab1/Rap1 to control neuronal migration and lamination in the neocortex. Neuron 69:482-497. CrossRef Medline

Fujioka T, Kaneko N, Ajioka I, Nakaguchi K, Omata T, Ohba H, Fässler R, García-Verdugo JM, Sekiguchi K, Matsukawa N, Sawamoto K (2017) $\beta 1$ integrin signaling promotes neuronal migration along vascular scaffolds in the post-stroke brain. EBioMedicine 16:195-203. CrossRef Medline

García-González D, Khodosevich K, Watanabe Y, Rollenhagen A, Lübke JHR, Monyer H (2017) Serotonergic projections govern postnatal neuroblast migration. Neuron 94:534-549.e9. CrossRef Medline

Ghashghaei HT, Lai C, Anton ES (2007) Neuronal migration in the adult brain: are we there yet? Nat Rev Neurosci 8:141-151. CrossRef Medline

Gheusi G, Cremer H, McLean H, Chazal G, Vincent JD, Lledo PM (2000) Importance of newly generated neurons in the adult olfactory bulb for odor discrimination. Proc Natl Acad Sci U S A 97:1823-1828. CrossRef Medline

Hack I, Bancila M, Loulier K, Carroll P, Cremer H (2002) Reelin is a detachment signal in tangential chain-migration during postnatal neurogenesis. Nat Neurosci 5:939-945. CrossRef Medline

Hanaichi T, Sato T, Iwamoto T, Malavasi-Yamashiro J, Hoshino M, Mizuno N (1986) A stable lead by modification of Sato's method. J Electron Microsc (Tokyo) 35:304-306. Medline

Hanke JH, Gardner JP, Dow RL, Changelian PS, Brissette WH, Weringer EJ, Pollok BA, Connelly PA (1996) Discovery of a novel, potent, and src family-selective tyrosine kinase inhibitor. study of lck- and FynTdependent T cell activation. J Biol Chem 271:695-701. CrossRef Medline

Haque A, Yue XS, Motazedian A, Tagawa Y, Akaike T (2012) Characterization and neural differentiation of mouse embryonic and induced pluripotent stem cells on cadherin-based substrata. Biomaterials 33:5094-5106. CrossRef Medline

Haque A, Adnan N, Motazedian A, Akter F, Hossain S, Kutsuzawa K, Nag K, Kobatake E, Akaike T (2015) An engineered N-cadherin substrate for differentiation, survival, and selection of pluripotent stem cell-derived neural progenitors. PLoS One 10:e0135170. CrossRef Medline

Hikita T, Ohno A, Sawada M, Ota H, Sawamoto K (2014) Rac1-mediated indentation of resting neurons promotes the chain migration of new neurons in the rostral migratory stream of post-natal mouse brain. J Neurochem 128:790-797. CrossRef Medline

Hirota Y, Kubo K, Katayama K, Honda T, Fujino T, Yamamoto TT, Nakajima K (2015) Reelin receptors ApoER2 and VLDLR are expressed in distinct spatiotemporal patterns in developing mouse cerebral cortex. J Comp Neurol 523:463-478. CrossRef Medline

Ishiyama N, Lee SH, Liu S, Li GY, Smith MJ, Reichardt LF, Ikura M (2010) Dynamic and static interactions between p120 catenin and E-cadherin regulate the stability of cell-cell adhesion. Cell 141:117-128. CrossRef Medline

Itoh Y, Moriyama Y, Hasegawa T, Endo TA, Toyoda T, Gotoh Y (2013) Scratch regulates neuronal migration onset via an epithelial-mesenchymal transition-like mechanism. Nat Neurosci 16:416-425. CrossRef Medline

Jinnou H, Sawada M, Kawase K, Kaneko N, Herranz-Pérez V, Miyamoto T, Kawaue T, Miyata T, Tabata Y, Akaike T, García-Verdugo JM, Ajioka I, Saitoh S, Sawamoto K (2018) Radial glial fibers support neuronal migration and regeneration after neonatal brain injury. Cell Stem Cell 22:128137.e9. CrossRef Medline

Jossin Y, Ogawa M, Metin C, Tissir F, Goffinet AM (2003) Inhibition of SRC family kinases and non-classical protein kinases $\mathrm{C}$ induce a reeler-like malformation of cortical plate development. J Neurosci 23:9953-9959. CrossRef Medline

Kanda Y (2013) Investigation of the freely available easy-to-use software "EZR" for medical statistics. Bone Marrow Transplant 48:452-458. CrossRef Medline

Kaneko N, Sawada M, Sawamoto K (2017) Mechanisms of neuronal migration in the adult brain. J Neurochem 141:835-847. CrossRef Medline

Kawauchi T, Sekine K, Shikanai M, Chihama K, Tomita K, Kubo K, Nakajima K, Nabeshima Y, Hoshino M (2010) Rab GTPases-dependent endocytic pathways regulate neuronal migration and maturation through $\mathrm{N}-\mathrm{ca}-$ dherin trafficking. Neuron 67:588-602. CrossRef Medline

Kempermann, G (2011) Adult neurogenesis 2. Oxford, UK: Oxford UP.

Kuo G, Arnaud L, Kronstad-O'Brien P, Cooper JA (2005) Absence of Fyn and Src causes a reeler-like phenotype. J Neurosci 25:8578-8586. CrossRef Medline

Lois C, Alvarez-Buylla A (1994) Long-distance neuronal migration in the adult mammalian brain. Science 264:1145-1148. CrossRef Medline

Lois C, García-Verdugo JM, Alvarez-Buylla A (1996) Chain migration of neuronal precursors. Science 271:978-981. CrossRef Medline

Luccardini C, Hennekinne L, Viou L, Yanagida M, Murakami F, Kessaris N, Ma X, Adelstein RS, Mège RM, Métin C (2013) N-cadherin sustains motility and polarity of future cortical interneurons during tangential migration. J Neurosci 33:18149-18160. CrossRef Medline

Luskin MB (1993) Restricted proliferation and migration of postnatally generated neurons derived from the forebrain subventricular zone. Neuron 11:173-189. CrossRef Medline

Matsunaga Y, Noda M, Murakawa H, Hayashi K, Nagasaka A, Inoue S, Miyata T, Miura T, Kubo KI, Nakajima K (2017) Reelin transiently promotes $\mathrm{N}$-cadherin-dependent neuronal adhesion during mouse cortical development. Proc Natl Acad Sci U S A 114:2048-2053. CrossRef Medline

Moreno MM, Linster C, Escanilla O, Sacquet J, Didier A, Mandairon N (2009) Olfactory perceptual learning requires adult neurogenesis. Proc Natl Acad Sci U S A 106:17980-17985. CrossRef Medline

Nanes BA, Chiasson-MacKenzie C, Lowery AM, Ishiyama N, Faundez V, Ikura M, Vincent PA, Kowalczyk AP (2012) p120-catenin binding masks an endocytic signal conserved in classical cadherins. J Cell Biol 199:365-380. CrossRef Medline

Ng KL, Li JD, Cheng MY, Leslie FM, Lee AG, Zhou QY (2005) Dependence of olfactory bulb neurogenesis on prokineticin 2 signaling. Science 308: 1923-1927. CrossRef Medline

Nishimura YV, Sekine K, Chihama K, Nakajima K, Hoshino M, Nabeshima Y, Kawauchi $\mathrm{T}$ (2010) Dissecting the factors involved in the locomotion mode of neuronal migration in the developing cerebral cortex. J Biol Chem 285:5878-5887. CrossRef Medline

Ogino T, Sawada M, Takase H, Nakai C, Herranz-Pérez V, Cebrián-Silla A, Kaneko N, García-Verdugo JM, Sawamoto K (2016) Characterization of multiciliated ependymal cells that emerge in the neurogenic niche of the aged zebrafish brain. J Comp Neurol 524:2982-2992. CrossRef Medline

Okuyama-Yamamoto A, Yamamoto T, Miki A, Terashima T (2005) Changes in reelin expression in the mouse olfactory bulb after chemical lesion to the olfactory epithelium. Eur J Neurosci 21:2586-2592. CrossRef Medline

Ono K, Tomasiewicz H, Magnuson T, Rutishauser U (1994) N-CAM mutation inhibits tangential neuronal migration and is phenocopied by enzymatic removal of polysialic acid. Neuron 13:595-609. CrossRef Medline

Onoue A, Takeuchi M, Kohno T, Hattori M (2014) Aberrant fragment of Dab1 protein is present in yotari mouse. Neurosci Res 88:23-27. CrossRef Medline

Ota H, Hikita T, Sawada M, Nishioka T, Matsumoto M, Komura M, Ohno A, Kamiya Y, Miyamoto T, Asai N, Enomoto A, Takahashi M, Kaibuchi K, Sobue K, Sawamoto K (2014) Speed control for neuronal migration in the postnatal brain by Gmip-mediated local inactivation of RhoA. Nat Commun 5:4532. CrossRef Medline

Peglion F, Llense F, Etienne-Manneville S (2014) Adherens junction treadmilling during collective migration. Nat Cell Biol 16:639-651. CrossRef Medline

Petri R, Pircs K, Jönsson ME, Åkerblom M, Brattås PL, Klussendorf T, Jakobsson J (2017) let-7 regulates radial migration of new-born neurons through positive regulation of autophagy. EMBO J 36:1379-1391. CrossRef Medline

Piedra J, Miravet S, Castaño J, Pálmer HG, Heisterkamp N, García de Herreros A, Duñach M (2003) p120 catenin-associated fer and fyn tyrosine kinases regulate beta-catenin tyr- 142 phosphorylation and beta-cateninalpha-catenin interaction. Mol Cell Biol 23:2287-2297. CrossRef Medline

Plachez C, Puche AC (2012) Early specification of GAD67 subventricular derived olfactory interneurons. J Mol Histol 43:215-221. CrossRef Medline

Porlan E, Martí-Prado B, Morante-Redolat JM, Consiglio A, Delgado AC, Kypta R, López-Otín C, Kirstein M, Fariñas I (2014) MT5-MMP regu- 
lates adult neural stem cell functional quiescence through the cleavage of $\mathrm{N}$-cadherin. Nat Cell Biol 16:629-638. CrossRef Medline

Saghatelyan A, de Chevigny A, Schachner M, Lledo PM (2004) Tenascin-R mediates activity-dependent recruitment of neuroblasts in the adult mouse forebrain. Nat Neurosci 7:347-356. CrossRef Medline

Sakamoto M, Ieki N, Miyoshi G, Mochimaru D, Miyachi H, Imura T, Yamaguchi M, Fishell G, Mori K, Kageyama R, Imayoshi I (2014) Continuous postnatal neurogenesis contributes to formation of the olfactory bulb neural circuits and flexible olfactory associative learning. J Neurosci 34: 5788-5799. CrossRef Medline

Sawada M, Huang S, Hirota Y, Kaneko N, Sawamoto K (2011a) Neuronal migration in the adult brain. In: Neurogenesis in the adult brain: I. Neurobiology (Seki T, Sawamoto K, Parent JM, Alvarez-Buylla A, eds), pp 337-355. Tokyo: Springer.

Sawada M, Kaneko N, Inada H, Wake H, Kato Y, Yanagawa Y, Kobayashi K, Nemoto T, Nabekura J, Sawamoto K (2011b) Sensory input regulates spatial and subtype-specific patterns of neuronal turnover in the adult olfactory bulb. J Neurosci 31:11587-11596. CrossRef Medline

Sawada M, Ohno N, Kawaguchi M, Huang SH, Hikita T, Sakurai Y, Bang Nguyen H, Quynh Thai T, Ishido Y, Yoshida Y, Nakagawa H, Uemura A, Sawamoto K (2018) PlexinD1 signaling controls morphological changes and migration termination in newborn neurons. EMBO J 37:e97404. CrossRef Medline

Sawamoto K, Wichterle H, Gonzalez-Perez O, Cholfin JA, Yamada M, Spassky N, Murcia NS, Garcia-Verdugo JM, Marin O, Rubenstein JL, Tessier-Lavigne M, Okano H, Alvarez-Buylla A (2006) New neurons follow the flow of cerebrospinal fluid in the adult brain. Science 311:629632. CrossRef Medline

Schaar BT, McConnell SK (2005) Cytoskeletal coordination during neuronal migration. Proc Natl Acad Sci U S A 102:13652-13657. CrossRef Medline

Sekine K, Kawauchi T, Kubo K, Honda T, Herz J, Hattori M, Kinashi T, Nakajima K (2012) Reelin controls neuronal positioning by promoting cell-matrix adhesion via inside-out activation of integrin alpha5betal. Neuron 76:353-369. CrossRef Medline

Sheldon M, Rice DS, D’Arcangelo G, Yoneshima H, Nakajima K, Mikoshiba K, Howell BW, Cooper JA, Goldowitz D, Curran T (1997) Scrambler and yotari disrupt the disabled gene and produce a reeler-like phenotype in mice. Nature 389:730-733. CrossRef Medline

Simó S, Pujadas L, Segura MF, La Torre A, Del Río JA, Ureña JM, Comella JX, Soriano E (2007) Reelin induces the detachment of postnatal subventricular zone cells and the expression of the egr-1 through Erk1/2 activation. Cereb Cortex 17:294-303. CrossRef Medline

Tamamaki N, Yanagawa Y, Tomioka R, Miyazaki J, Obata K, Kaneko T (2003) Green fluorescent protein expression and colocalization with calretinin, parvalbumin, and somatostatin in the GAD67-GFP knock-in mouse. J Comp Neurol 467:60-79. CrossRef Medline

Tomasiewicz H, Ono K, Yee D, Thompson C, Goridis C, Rutishauser U, Magnuson T (1993) Genetic deletion of a neural cell adhesion molecule variant (N-CAM-180) produces distinct defects in the central nervous system. Neuron 11:1163-1174. CrossRef Medline

Wichterle H, Garcia-Verdugo JM, Alvarez-Buylla A (1997) Direct evidence for homotypic, glia-independent neuronal migration. Neuron 18:779791. CrossRef Medline

Wu S, Esumi S, Watanabe K, Chen J, Nakamura KC, Nakamura K, Kometani K, Minato N, Yanagawa Y, Akashi K, Sakimura K, Kaneko T, Tamamaki N (2011) Tangential migration and proliferation of intermediate progenitors of GABAergic neurons in the mouse telencephalon. Development 138:2499-2509. CrossRef Medline

Yagita Y, Sakurai T, Tanaka H, Kitagawa K, Colman DR, Shan W (2009) $\mathrm{N}$-cadherin mediates interaction between precursor cells in the subventricular zone and regulates further differentiation. J Neurosci Res 87: 3331-3342. CrossRef Medline

Yoneshima H, Nagata E, Matsumoto M, Yamada M, Nakajima K, Miyata T, Ogawa M, Mikoshiba K (1997) A novel neurological mutant mouse, yotari, which exhibits reeler-like phenotype but expresses CR-50 antigen/ reelin. Neurosci Res 29:217-223. CrossRef Medline

Yue XS, Murakami Y, Tamai T, Nagaoka M, Cho CS, Ito Y, Akaike T (2010) A fusion protein $\mathrm{N}$-cadherin- $\mathrm{fc}$ as an artificial extracellular matrix surface for maintenance of stem cell features. Biomaterials 31:5287-5296. CrossRef Medline

Zisch AH, D’Alessandri L, Amrein K, Ranscht B, Winterhalter KH, Vaughan L (1995) The glypiated neuronal cell adhesion molecule contactin/F11 complexes with src-family protein tyrosine kinase fyn. Mol Cell Neurosci 6:263-279. CrossRef Medline 